\title{
GOLDEN GENERATION PREPARATION AND ITS CONTRIBUTION TO THE MODERATE GLOBAL RELATIONS
}

\author{
Ali Unsal \\ Former Director of Fethullah Gulen Chair at UIN Syarif Hidayatullah, Jakarta-Indonesia \\ aliunsal5@hotmail.com
}

\begin{abstract}
The Golden Generation is the most beautiful fruit of human beings. The symbol of love and peace, which beautifies the life of the world, brings matter and meaning in balance, represents good morality, in short, it is the projection of the "insan-ı kamil" Muhammad pbuh and his companions in every century. The Golden Generation is an open-minded and compassionate generation that combines Islamic values with modernity, can integrate with the whole world. Within the framework of this article, we will try to examine what the "Golden Generation" concept used by M. Fethullah Gulen in the last 50 years includes, how they were raised, what they did, and especially what kind of its contribution they do to the moderate global relations. In doing so, we will include the testimony and reports of researchers, academics, scientists, clergymen, intellectuals, writers, and statesmen from different parts of the world to be objective.
\end{abstract}

Keywords: Golden generation; education; Gulen; moderate; Islam.

\begin{abstract}
Abstrak: Generasi Emas adalah buah manusia yang terindah. Simbol cinta dan damai yang mempercantik kehidupan dunia, membawa materi dan makna dalam keseimbangan, melambangkan moralitas yang baik, singkatnya, itu adalah proyeksi dari "insan-ı kamil" Muhammad SAW dan para sahabatnya di setiap abad. Generasi Emas adalah generasi yang berpikiran terbuka dan welas asih yang menggabungkan nilai-nilai Islam dengan modernitas, dapat berintegrasi dengan seluruh dunia. Dalam kerangka artikel ini, kami akan mencoba mengkaji apa saja konsep "Golden Generation" yang digunakan oleh M. Fethullah Gulen dalam 50 tahun terakhir ini, bagaimana mereka dibesarkan, apa yang mereka lakukan, dan terutama kontribusi apa yang mereka lakukan. untuk hubungan global yang moderat. Dalam melakukannya, kami akan memasukkan kesaksian dan laporan para peneliti, akademisi, ilmuwan, pendeta, cendekiawan, penulis dan negarawan dari berbagai belahan dunia agar objektif.
\end{abstract}

Kata Kunci: Generasi emas; pendidikan; Gulen, moderat, Islam.

\section{A. Introduction}

Youth is one of the most important dynamics of a nation. Nations that rely on their youth can look to their future with hope because young people will build the future. On the other hand, nations that have not been able to raise their young people well and give their own identities with their own values they will lose their nationality to a certain extent and they will be forced to live under the guidance of other nations.

What are our expectations for the future from the youth that we call "millennium youth" today? Are we happy with this youth? And are we hopeful about them for the future? First of all, we have to find an honest answer to these questions. After that, we have to determine an action plan and follow the rules step by step. At this point, some are very optimistic and some are very disappointed.

The importance of the Golden Generation, which is the subject of our study, increases even more under these conditions. The Golden Generation has actually been the dream of many scholars, philosophers, thinkers, educators, statesmen, and leaders who took place on the stage of history. While Campanella was writing his book "The State of the Sun", or Plato was writing his "Republic", and Thomas More had always dreamed to pursue the such of a generation while 
looking for ways to get rid of the dark thoughts of the Middle Ages. Farâbî, with his al-Medinatul Fadila, also dreamed such a generation and a town molded with virtue that will be their work.

When we look at the lives of the prophets in the course of history, we see that they give importance to youth while they are bringing peace and happiness to humanity, calling them to the right path, and guiding them in almost every field, -and as a quirk of fate-, we see that the young people are around them. For example, besides Moses a.s. there was Joshua b. Nûn, Jesus himself represents soul of youth, and we see that many other young companions like Abdullah b. Mesud Hz. Ali, Hz. Abdullah b. Zubair were besides of Rasûlullah pbuh in the past. If we look at their ages, Hz. Ali was 10 years old when he became a Muslim, Zaid b. Hâritha 15, Abdullah b. Umar 10, Abdullah b. Zubair 7-8, Jafar b. Abi Talib 17, Abdullah b. Mas'ud and Zubair b. Awwâm 16, when he came to Aqaba allegiance, Jabir b. Abdillah was 15 and the three great names of Companions Promised Paradise (Ashara Mubashara) Hz. Uthman, Hz. Abu Ubaidah b. Jarrah and Hz. Omar were between 25 and 31 years old. ${ }^{1}$ The valiant representatives of this position, which was later called "futuwwah" 2 in the Islamic literature, are the heroes of the altruistic direction who have surrendered to the cause they believe with all their hearts, devoted everything to this path and never drew zig and zag. It can be said that Islam initially flagged on these young shoulders. These young people, who took their discipline from the Messenger of Allah personally, later became teachers, guides and role models for all humanity.

The fact, a matter is that every sane believer would desire that today's youth would be a Golden Generation like the distinguished heroes of the Age of Happiness. We will try to discuss and try to find an answer in this humble work that is it possible to grow a new Golden Generation? What is needed for this? Are there any studies already done? What are the fruits of these studies?

\section{B. Golden Generation snd Its Characteristics}

The Golden Generation is an ideal. It is a goal. We first see this statement in the conferences, writings and books of Mohammed Fethullah Gulen, one of the man of mission or sufferer of this century. What does he mean by the Golden Generation? It is understood in his expressions that the "Golden Generation" must be a version of the enlightened generation in this century that stood behind our Prophet in the age of happiness. That is, it should carry their personalities and realize their mission. Gulen first of all believes that his own country could be saved from social turmoil, betrayal, immorality, bribery, theft, indecency, hypocrisy, political and social conflicts, and socialeconomic problems only by virtue of this educated generation. Then, the common problems of the Islamic world even big challenges of humanity could be solved by virtue of them. This example from his life shows us that this view is an ideal of his life. One day, he got into his room at the end of his lesson, took a book from the library and gave to one of his prominent students saying "Either be like these or perish". The book was "Hayat al-Sahabah" (The Lives of the Sahabah)

Now, let's take the issue what are the characteristics of the "Golden Generation" that is ideally aimed to be trained?

\section{Strong Faith}

The first characteristic of the Golden Generation is its strong belief. He/she must, for the sake of the cause he has given his heart to, be resolved to cross over seas of "pus and blood".

$\mathrm{He} / \mathrm{she}$ is faithful to the cause to which he has devoted his life that, deeply in love with it, he can sacrifice his life and all that he loves for its sake. So sincere and humble that he will never bring to mind all that he has accomplished. ${ }^{3}$

Such a young person who has a belief free from any doubt, will be able to protect himself from the enthusiasm of the youth, the deceit of the innate devils and the traps of his nafs. He/she

1 İbrahim Sarıçam, Hz. Muhammed ve Evrensel Mesajı, (Ankara: 2001), 304-305.

2 Futuwwah, defined as youth and chivalry, is really a composite of such virtues as generosity, munificence, modesty, chastity, trustworthiness, loyalty, mercifulness, knowledge, humility, and piety. M. Fethullah Gulen, Key Concepts in the Practice of Sufism: Emerald Hills of the Heart (New Jersey: Tughra Books, 2009), v. 1, p. 81.

3 Gulen, Fethullah, “Pearls of Wisdom”, Tughra Books, New Jersey, 2007, p. 103. 
will never fall into despair while being crushed under the pressure of incidents from time to time. $\mathrm{He} /$ she will always have good wishes towards Allah and will act with his self-motivation. He will not need anyone to direct or encourage him/her. In the most difficult moments, he will rise up with the hope that Allah will help him/her and he/she will use his/her willpower on the right path. As such, the slopes will be straight and the flat ones will become smooth on his/her way. The deviant and perverted ideas, philosophical approaches, and some false currents imposed by modernity that emerge in the world will not deviate him from the truths he believes in, and he/she will always go head on the right direction. Thanks to this strong faith, this hero will not only save himself/herself, but will present Khidr breaths to everyone he has a relationship with, will also be a source of light to those who are drowned for various doubts and hesitations, oppressed under the pressure of incidents, and drowned in the darkness of harmful thoughts and habits. ${ }^{4}$

\section{Establishing Balance Between Material and Spiritual}

The Golden Generation will grasp the nature of human well. He/she will know that he/she does not only have a biological structure such as hands, feet, eyes, ears, kidneys and spleen, but also has a deeper and deeper spiritual aspect than it. According to him, he will know and evaluate the relations between material and spiritual very well. As the Nobel Prize-winning physiologist Alexis Carrel points out, everyone will know that this inner depth is much deeper than the outside like the iceberg.5 Here is the Golden Generation knows how the body needs food to nourish it. Just like this, he knows that his/her soul, which represents his spiritual side, needs nourishment. For this, he/she takes the necessary spiritual education in order to raise himself/herself. Afterwards, he/she tries to find between the hadith of the hadith, "You should see yourself as a strange, a traveler in this world" 6 and the hadith that says "A strong believer is better than a weak believer."7 For this, he becomes planned, programmed, determined, diligent, assiduous and hardworker in every work he/she undertakes. After doing everything in his/her power to succeed, this is called practical prayer, then prays and begs for the help of his Lord, which is also called verbal prayer. After embracing the causes, he meets the result with trust in Allah. Just like Jalaluddin Khwarazm Shah, who repeatedly defeated Genghis Khan's armies. He had made all the preparations before a war. The people beside him said, "You will be victorious. Allah Almighty will win you over." He said: "I am obliged to act in the way of jihad by the order of Allah. I do not interfere with the duty of Allah Almighty. It is His duty to make triumph or defeat." 8 Yes, the Golden Generation, after doing its part, will be pleased with the will of Allah with great trust.

He always does his works as regarded to the afterlife. He is aware that what he does will be reckoned with by God one day. Just as in the 105th verse of the Surah Tawbah Allah tells us, "And say, "Do [as you will], for Allah will see your deeds, and [so, will] His Messenger and the believers. And you will be returned to the Knower of the unseen and the witnessed, and He will inform you of what you used to do."

So, he will act carefully and rigorously as if he was presenting it to their inspection. However, he will never make material targets his life's goals. That is, to appropriate an office, to attain a material power, to have an authority or to obtain a material interest will never be its goal and main purpose. Golden Generation has only one goal. It is to earn the "consent/pleasure of Allah". Since he will know well that the way of this consent is to serve people and creatures, he will know well the means that lead to the goal. He will give only value them as much as they deserve. He will never put any of them in the place of Allah's consent. He will know that making

4 Gulen, Fethullah, "Yenilenme Cehdi", Kırık Testi-12, "Adanmışlık Ruhu ve Hayat Standardı", Blue Dome Publishing, NJ, 2016, p. 209. See: http://fgulen.com/tr/eserleri/kirik-testi/kullukta-derinlesme; http://fgulen.com/tr/eserleri/kalb-ibresi/dine-hizmet-mazhariyeti;

5 See: Carrel, Alexis, "Man the Unknown", Harper \& Brothers, 1939. (https://web.archive.org/web/20180920164410/http://hpaba.com/pages/en/ALEXIS\%20CARREL\%20Man \%20the\%20Unknown\%201935.pdf)

6 Tirmidhi, Zuhd, 25.

7 Muslim, Kadar, 34; Ibn Majah, Muqaddimah, 10

8 Nursi, Bediuzzaman Said, Lemalar (Flashes), 17. Lem’a, Şahdamar Publishing, Istanbul, 2014, p. 163. 
occasions a goal is a great danger. Just as The Almighty Creator stated in the Quran: "But seek, by means of what God has granted you, the abode of the Hereafter (by spending in alms and other good causes), without forgetting your share (which God has appointed) in this world. Do good to others as God has done good to you (out of His pure grace). Do not seek corruption and mischief in the land, for God does not love those who cause corruption and make mischief." (28 Qasas, 77). He takes his lesson that the main goal is to win the hereafter, and the world will only take its place in the heart to the extent that it does not forget its share. Thanks to this balance, while running towards the target, he will not get stuck on the fun toys and candies on the road, he will not zigzag and walk directly to his target. He will not be aware of the achievements and blessings Allah bestows from himself; being aware that he has been bestowed as a gift from Allah, he sees it as a necessity of gratitude towards Allah to share his blessings with others and to help others. Since he knows that the blessing comes from Allah, he will never enter into vanity, arrogance, pomposity, and conceit.9

\section{Love and Affection}

The Golden Generation will know that the essence of the universe is molded and kneaded with love. He will know well that God has kneaded the earth with many beautiful names such as Rahman, Rahim, Kareem, Jamil and Wadûd. Ustad Bediuzzaman states that the purpose of human being to the world is to know and love Allah with the following words? "Be certain of this, that the highest aim of creation and its most important result is belief in God. The most exalted rank in humanity and its highest degree is the knowledge of God contained within belief in God. The most radiant happiness and sweetest bounty for jinn and human beings is the love of God contained within the knowledge of God. And the purest joy for the human spirit and the sheerest delight for man's heart is the rapture of the spirit contained within the love of God. Yes, all true happiness, pure joy, sweet bounties, and untroubled pleasure lie in knowledge of God and love of God; they cannot exist without them."10

The heroes of the Golden Generation approach things and events with their hearts full of this divine love. Therefore, they have great love, compassion and compassion for being. That is why they love the created because of the Creator. ${ }^{11}$ They love the love, they become enemies of hostility. ${ }^{12}$ First of all, they love their brothers and sisters who serve the Quran and Islam like themselves. Then they love all believers, then all humanity, then all living things and all beings according to their levels.

He accepts man as the most ancient art of God. He feels affectionate for some and compassion for some because Allah gives them value. He loves love, is hostile to hatred and hostility. Another name for them is "love chivalrous". Everyone who sits with them, family members, friends, friends and neighbors always see the work of love in him. They never hold grudges or hate anyone. They only put distance to those who need to distance themselves in necessary. Most of these people who are likely to be harmed by them. This is only exemption for them. Because these young people act in accordance with the philosophy of Rumi "No candle loses anything from its light by igniting another candle"13, and they desire to share their love and affection with everyone. They always transfer their positive energy, love and affection to others. They follow their only guide, The Pride of Mankind Hz. Muhammad Mustafa pbuh, as stated by mother of Muslims Aisha, Rasûlullah did not hold a personal grudge against anyone. He advised Enes not to hold grudges against anyone. ${ }^{14} \mathrm{He}$ opened his heart to everyone. Even his most violent enemies could find the peace in that sea of compassion. Abu Sufyan, his wife Hind, Wahshî, Safwan b. Umayyah, Ikrimah b. Abi Jahl and many others hated him the most an hour ago, their hearts

9 http://fgulen.com/tr/eserleri/prizma/mantik-ve-his-dengesi

10 Nursi, Bediuzzaman Said, The Letters, Twenteeth Letter, Şahdamar Publishing, Istanbul, 2014, pp. 254-255.

11 Gulen, Fethullah, Prizma-3, 6. version, Nil Publishing, Izmir, 1999. p. 104.

12 Gulen, M. Fethullah, Ölçü ve Yoldaki Işlklar, Nil Publishing, Izmir, 2011, p. 113.

13 Ulu, Ömer, Gediğini Arayan Taşlar, Istanbul, Sistem Matbaacılık, 2001, p. 247.

14 Tirmidhi, Ilm, 16. 
melted when he embraced them with compassion and stated that he was the person they loved most an hour later. 15

They find a common point in everything and establish a connection with them in terms of being the creature of God. In this respect, the Golden Generation is a good friend and comrade, a good neighbor, a good relative, and a good citizen. He is a person who is open to dialogue, accepts everyone in their own position, is open to sharing the goodness and cooperating with everyone who is legitimate in combating common enemies of humanity (such as drugs, terrorism, environmental problems, persecution etc.). He/she is helpful and also a good environmentalist. Because he/she is aware that he/she is a member of ummah of a prophet the hero of compassion and guidance, who saw a burned anthill at one time, and he was very angry with those who did it then forbade his ummah to do that. ${ }^{16}$ On the same journey, he was very uncomfortable when he saw the bird pervading around the nest because his baby was taken from his nest and asked that the baby be put in the nest immediately. ${ }^{17}$ In another time, after a war he was watching a woman looking for her little baby, she was running from there and looking at each baby she sees, finally finding her baby and giving her milk. He couldn't hold back his tears, and then asked his companions, "Will this woman throw her child into the fire?" They said, "No, he does not throw, 0 Prophet." Then he gave his lesson saying "Allah is much more merciful than this woman."18

The Golden Generation also loves its mother, father, spouse, children, home, homeland etc. However, his/her love is the basis of love of God. He loves all others depending on that affection. He loves the world as a field of the hereafter. However, he never places the love of mortal worldly things in his heart, independent of God. This makes him stronger against the miserable and deceptive beauties of the world and the snares of Satan. In other words, the money he earns is in his pocket, not his heart. He doesn't put it in his heart. Because there is God in the heart. Since it is full, other things cannot find a place there. What is the practical consequence of this? The Golden Generation cannot be earthly. He cannot be a machiavellian. That is, while reaching the goal, it does not proceed by violating its values and Allah's orders. He likes to share. He finds peace when he shares. He is far from stinginess, profiteering and selfishness. As in Mevlânâ Rumi's metaphor of the ship, he looks at the world as a tool and occasion. Rumi makes an analogy as follows. The water under the ship makes the ship float. But if you take the same water into the ship, it will sink the ship. This is the position of world goods and beauties. It is given to him/her to do good things and good things with them. If he puts them in his heart, he feels great anxiety and sadness because of thinking and scaring of their disappearance. ${ }^{19}$ Because of that, he becomes selfish, stingy, offensive and overwhelming. He cannot empathize with someone else. Now his heart is sick because he put the wrong things into his heart.

The Golden Generation possesses great love and compassion, especially at the point of saving people's eternal life. In other words, he feels great sadness in the face of people's becoming monstrous in the world by obeying their eagerness and enthusiasm and rolling to Hell eternally in the hereafter. As a result of this compassion, he tries to reach out to everyone, to give a place in his heart and to invite him to a life of Heaven by holding his hand.

This generation is forgiving because it is the hero of love. Because life does not always go beautiful and monotonous. Often there are ups and downs. Therefore, he always remembers his only guide how the Prophet embraced existence with love and compassion. He tries to resemble the Prophet, the hero of compassion who forgives his biggest enemies, tyrants who oppress, torture and martyr his friends, companions, and relatives when he has power against them. This generation tries to approach with compassion and forgiveness as much as he can those he does

\footnotetext{
15 Muslim, Fazailussahaba, 59; Tirmidhi, Zakat, 30; Ibn Sa'd, Tabaqat al Kubra, v. 6, h. no. 6734.

${ }^{16}$ Abu Dawud, Jihad, 12; For His teaching to respect their lives Bukhari, Jihad, 152; Muslim, Salam, 148.

17 Abu Dawud, Jihad, 12.

18 Bukhari, Adab, 18, Muslim, Tawba, 22.

19 Mevlana Celaleddin Rumi, Letters, Trans. Abdülbaki Gölpınarlı, Istanbul, 1953, p. 36
} 
not agree with and who is bad at all. On the other hand, he gets up at night begs, prays in the tahajjud and asks God to help him soften his heart where/when he is stuck. ${ }^{20}$

\section{Depth of Worship and Prayer}

The Golden Generation is the human who lives his faith. He/she has a deep world of prayer, supplication, and servitude to Allah. He is sensitive to his prayers. He even plans his daily life based on prayer/salah. He enriches his fards (obligatory duties) with nafilahs (voluntary acts). Especially the night prayer, especially the night prayer... He places a special emphasis on prayers and prayers. They think that a person who does not have wirids (dhikir, tasbih, prayers) has no waridat (benevolence, kindness, and extra Divine bounties). ${ }^{21}$ In other words, this distinguished generation places a special emphasis on reading prayers and dhikrs (invocation) in order to keep its connection tightly with Allah. If possible, they do prayer glorification together and with enthusiasm. This both binds them together and connects them to Allah. The Quran is a part of their lives. In addition to reading it, since they consider themselves to be the students of the Qur'an, they have daily exchanges of ideas and discussions on how to read, understand and live it. The Golden Generation knows well that unless it has a good relationship with God, it cannot have a good relationship with people. He/she always seeks God's help in establishing a good relationship with people. ${ }^{22}$

\section{Action}

The Golden Generation is above all active in doing what it believes in. That is, he/she always fulfills the requirements of his belief, first in worship and then in other transactions or dealings. First of all, he applies the draft of rules that include high human values, which are the basic principles of his life, in his own life in a disciplined manner. Then it shares these beauties with all humanity, starting from the closest. As explained in Chapter al-Asr, people should see time as a capital given to them. Unfortunately, most of the people have lost in this regard. However, with the exception of those who believe and do good deeds, that is, those who first conquered the inner conquest and then advise each other to obey the rights, the righteous, the good, the rights of others, the rights of Allah, and all kinds of hardship and difficulties they face while fulfilling them. When faith enters a heart, it starts to smell nice. A beauty occurs in the attitude of a person who has a heart filled by faith, and this is also observed by his surroundings. Here is the Golden Generation acts just like its unique leader Hz. Muhammad sallallahu alayhi wa sallam. He did not spend his time only believing and doing righteous deeds. If it were, He would stay in seclusion in his cave Hira and do it in the best way possible. However, He has put forth everything, including his life, to carry the messages sent to him to other hearts at all costs, to deliver water to the barren land, to illuminate the dark places, and to replace anarchy and terror with peace and happiness. For this cause, he lost his closest relatives and was subjected to torture and exile. However, he never took a grudge or revenge against anyone. ${ }^{23}$

The Golden Generation does not pass a day without notification, guidance, amr bi'l-ma'rûf nahy ani'l-munkar. He regards such a day as not experienced. In fact, its action is maybe one step ahead. He sees stagnation as the most important reason for fading, waning, and ending. Just as, in the analogy of Ustadh Bediuzzaman, the sun is always in its orbit, without stopping. If it stops just a little bit, the planets around it will fall off, like the fruits of the tree, and be thrown left and right.24 The Golden Generation, which has devoted itself to serving humanity, never accepts to be idle.

20 See: Gulen, M. Fethullah, Yitirilmiş Cennete Doğru, Nil Publishing, Izmir, 2011, pp. 104-107; http://www.herkul.org/tag/sefkat/; http://www.herkul.org/tag/sevgi/

${ }^{21}$ https://www.youtube.com/watch?v=y5_fziEORps

22 http://www.herkul.org/kirik-testi/kirik-testi-kullukta-derinlesme/; $\quad$ http://www.herkul.org/kiriktesti/kirik-testi-kullukta-derinlesme/; https://fgulen.com/tr/eserleri/namaz/islam-hakikati?start=6

23 Bukhari, Manâqıb, 23; Adab, 80; Muslim, Fazail, 77; Abu Dawud, Adab, 4; Muwatta, Husn al-Khuluk, 2; Ahmad b. Hanbal, Musnad, v. 5, pp. 130, 223, 232.

${ }^{24}$ Nursi, Bediuzzaman Said, İşaratü'l-İ'câz fî Mazanni'l-Îcâz, Şahdamar Publishing, Istanbul, 2014, p. 120. 


\section{Murāqabah (Self-Supervision)}

The Golden Generation is a serious person in murâqabah. It is always in contact with God. When he do a job he always acts with thought "I wonder if my Lord is pleased with this job?". While doing that job, he renews his intention over and over again with the consideration of "how can I stand upright against the traps of my soul/nafs and the devil". If he can achieve success when the work is done, he will know it as a blessing from Allah, and he will never get into the drunkenness of conceit and victory. Even if he loses, he takes lessons from the mistakes and seeks the result by being pleased with his Lord. He never seeks scapegoats and neither damages his brotherhoods, destroys his unity and solidarity, nor prepares the ground for hopelessness and the collapse of his motivation. He always believes that whatever God has appointed for him is the best. He never forgets his shortcomings and faults, always begs in prayer to his Lord, and is always based on His power. He is pleased with what comes from Allah. He approaches the destiny of his Lord with trust, and his heart is pleased with Him. He knows the same and pleased what comes from Him even pain or grace. He is always in muraqabah (being on the way to Him at all times with overwhelming glorification, inciting nearness and urging joy). So, he is with Allah among people. Even if he is in the dungeon, he is not alone, but with Him, even though he is among large crowds. That's why his heart is always honest and awake. He does not like heedlessness. ${ }^{25}$

\section{They Believe in Peace and Dialogue}

The "Golden Generation" or the "People of Service" 26 believe that nothing can be achieved from turmoil, quarrel, anarchy. They are the representative of peace, security, trust and peace where he/she is located. He/she tries to avoid conflicts, to reconcile and unite them as much as they can. Therefore, the institutions they serve are "Islands of Peace or heaven of peace" in Thomas Michel's words. ${ }^{27}$ There is never room for extreme nationalist thinking, racist attitudes and discourses, or humiliation of anyone because of their religion or sect. He tries to keep the culture of coexistence alive by finding common points with almost everyone. He engages in dialogue with everybody in around, identifies common issues and tries to find solutions to some common problems together. The Golden Generation sincerely believes that peace is better with the expression of the Quran ${ }^{28}$ and believes that the religion of Islam derives from the root "silm" and means peace. ${ }^{29}$ Therefore, he believes that a Muslim should always support peace and tranquility. He believes that The Pride of Mankind Hz. Muhammad Mustafa pbuh was sent as a mercy to all humanity, to bring happiness to humanity. That is, he believes that He is a prophet of compassion, not a "prophet of war" as others suggest. For, according to historical sources, he fought in warm contact only 13 hours of his prophecy of 23 years, that is, 8000 days. While the number of Muslims who were martyred in these wars was around 150, the number of people who died from the opposite side was limited to 250.30

25 Gulen, Fethullah, Emerald Hills Of The Heart Key: Concepts In The Practice Of Sufism, Tughra Books, NJ, 2011, v. 1, pp.59-62; http://www.herkul.org/bamteli/gaflet/; http://www.herkul.org/tag/gaflet/; Gulen, M. Fethullah, Buhranlı Günler ve Ümit Atlasımız, "Gaflet ve Ülfete Yenik Düșmemiș Dua", Nil Publishing, Izmir, 2015, pp. 92 97; http://www.herkul.org/kirik-testi/kirik-testi-dusunce-ve-aksiyon-insani/; http://www.herkul.org/bamteli/bamteli-sadakat-iksiri-ve-duraganlik-zehri/

26 Gulen sometimes calls the volunteers and Golden Generation as "people of service".

27 Michel Thomas, "Fethullah Gulen as Educator", Turkish Islam and the Secular State: The Gulen Movement, ed. M. H. Yavuz and J. L. Esposito, Syracuse, NY, Syracuse University Press, 2003, pp. 69-84

28 Quran, Chapter "Nisa", 4/128.

29 Ibn Manzûr, Ebu al-Fazl Jamâluddîn Muhammed b. Mukarram b. Ali b. Ahmad al-Ansârî er-Ruwayfî, Lisânu'lArab, Dar al-Sadr, Beirut 1994, v. 12, p. 295; Shahristânî, Abu al-Fath Muhammed b. Abdülkerim, el-Milel ve'nnihal, Dâru'l-Marife, Beyrut 1993, v. 1, p. 53; Ibn Taymiyyah, Abu Abbâs Takıyyuddîn Ahmad b. Abdulhalim, Kitâb al-Imân, al-Maktaba al-Islâmiyye, Beirut, 1996, p. 283; Ibn Furak, Abû Bakr Muhammad b. Hasan, al-Mujarrad fî makâlât-ı Abî Hasan al-Ash'arî, Maktabat al-Saqâfat al-Dîniyye, Cairo, 2005, p.157; Ibn Hazm, Abû Muhammed Ali bin Ahmad bin Saîd, al-Fasl fi al-milal wa'lahwâ wa al-nihal, Dar al-Jeel, Beirut 1996, v. 3, p. 269.

30 Dr. Reşit Haylamaz give this info according his research. See: https://www.youtube.com/watch?v=NgSGQDtSY8; https://www.youtube.com/watch?v=dCg5AHvTgos 
Considering the reasons, the main reason of none of them was Rasûlullah pbuh, almost all of them were either fought in a defensive war against the attacking party, either went on those who were preparing for the attack, or had to go against the groups who violated the agreements and were constantly sources of strife, and he efforted to ensure peace. Yes, he fought, but he fought because he had to. We can understand this from his attitude after the wars are over. To give the captives of Badr their freedom if they teach ten people to read, ${ }^{31}$ to return their wives and children to those who came to Islam at the end of the Battle of Hunain ${ }^{32}$, to go over the Meccans who broke the treaty and to warn his companions not to fight unless they have to when they conquered Mecca, and then to forgive his chief enemies who tormented him for years ${ }^{33}$. The fact that he allowed Jews, who did not cause any problems, to live in Madinah until his death ${ }^{34}$ and many other examples are the facts that reveal how sincere he is in this regard. On the return of Ta'if, his word to Jibril a.s. also expresses this "I was not sent for torment. I am a prophet of mercy. If anyone is going to believe from their generation, I never want them to be destroyed." 35 These are the things that show that he came to all mankind to establish peace and tranquility. Here, the Golden Generation always lives based to keep alive. In fact, they code their lives as "living to live". In addition, they respect everyone's life, property, belief, opinion and freedom by accepting everyone in their own position. Although he/she receives great criticism from time to time, he/she believes that dialogue is the most important activity that will help people understand and respect each other. ${ }^{36}$ Therefore, regardless of the religion, race, sect and opinion of people around him, he believes that he has a duty to engage in dialogue, visit, invite them and, if possible, make projects with them on behalf of humanity. ${ }^{37}$

\section{Sacrifice}

The Golden Generation works like a bee, produces honey and offers it to humanity. He gives milk like a sheep, but he does not think of using it. Sacrifice is his life system. He knows very well that no success can be achieved without sacrifice. While their peers are in pursuit of some worldly pleasures, having fun, traveling and hanging out, the Golden Generation thinks of spending their time in the most efficient way and living to the fullest. While doing this, he/she experiences the character of Isâr (preferring the lives and happiness of others over one's own) ${ }^{38}$ by seeing the needs of others before his/her own. He is ashamed to be remembered for his actions but does not even desire to see the victory39. He/she heeds this advice "You throw seeds and go, whoever harvests it!.." That is, he/she never says "I will definitely collect the fruits... I will be rewarded... I will collect applause for what I will do... I will be admired... I will be remembered..." They do their duties only for the sake of Allah without making any kind of demands, any requests!

In this respect, the teacher who put all his students to bed and stayed overnight on the chair because there was no space left, the educator who jumped into the river to save his student from drowning and lost his own life, the mentor who constantly wandered around the dormitory at night to cover his students at nights, if there was someone who cried, sat down and took care of him for hours, a university student bought food for his friends who were in trouble with the money he saved to buy shoes, a teacher who rushed with enthusiasm for months without a salary and

31 Ibn Sa'd, Tabaqat, v. 2, p. 22; Ahmad b. Hanbal, Musnad, v. 1, p 246.

32 Haylamaz, Reşit, Gönül Tahtımızın Eşsiz Sultanı Efendimiz sallallahu aleyhi ve sellem, Işık Publishing, Izmir, 2007, v. 2, pp. 560-571.

33 Bukhari, Maghazi, 56; Muslim, Cihad, 134, Birr, 144, Zekat, 135; Tirmidhi, Birr, 45, Et'ıme, 30, Tefsir, 33.

34 Bukhari, Rahn, 2, 5, Buyu', 14, 33, 88, Silm, 5, 6, Istiqraz, 1, Jihâd 89, Maghazi, 85; Muslim, Musâqât; Nasâî, Buyu', 58, 87.

35 Bukhari, Badu'l-Khalk, 59.

36 Gulen, Fethullah, Toward a Global Civilization of Love \& Tolerance, The Light Inc, NJ, 2004, p. 77.

37 Se efor more info: Gulen, Fethullah, Advocate of Dialogue, Compiled by Ali Unal, Alphonse Williams, Fountain, 2000.

38 See, Qur'an, Chapter 59:9.

39 They like literature and often use literary arts. They use for the time of successful, prosperity, and victory "gül devri" (rose age). That is, they call the time of struggling, time of sacrificing, working hard, and overcoming the problems is "autumn or winter", and time of seeing the fruition of their work is called "spring". 
without lowering his motivation, the education hero cried at the sins of his/her students, the manager who worked like a labor in the construction of his school, the education volunteer who got up quietly at night and cleaned the toilets of the dormitories.. they were all from Golden Generation. On the other hand, a businessman like Hz. Abu Bakr spent his all wealth on Allah's way, a tradesman like Hz. Umar gave half of his property; someone is like Hz. Uthman, someone like Hz. Ali, someone like Hz. Abdurrahman b. Awf many business trustees who gave their wealth to the way of Allah that the mind could hardly accept, the housewife who took off his bracelet and earring when they saw the poor students need scholarship, the trustee sisters who tried to meet the needs of poor students by organizing charity programs even in cold weather and many more altruistic people are Golden Generation. Young people went as teachers to mountain cities where even the car could hardly reach, the idealist young people who went to work as doctors, nurses, policemen, prosecutors, judges, civil servants and teachers while fleeing from the towns where terrorism prevailed and more. They always migrate to countries thousands of kilometers away which they heard those countries names the first time and they do not even know their languages, to share their beauties, to give what they know, to take what they do not know from them. These distinguished immigrants (muhajir and muhajira), who made many more sacrifices without expecting anything in return, are members of the Golden Generation. You can see these examples and more than these in their life. ${ }^{40}$

\section{Tear}

The Golden Generation is a person of heart. He/she takes good examples from each of the prophets who came to guide humanity. Especially, it is a very important characteristic for him that they shed tears due to their deep control (muraqabah) and their connection with their Lord. He also gives a special value to tears in the Prophets' footsteps. He is afraid that he will not understand if he does not cry. He does not see crying as a weakness. On the contrary, he accepts the tears as the translator of a heart filled with skill, virtue and wisdom. One of the seven groups of people who will be shadowed in the shadow of the Throne of Allah in the hereafter mentioned in the hadith, he desires to be one of those who "remember God when he is alone and weeps." 41 He takes both the warnings of the Quran and the hadith of our Prophet pbuh, "If you knew what I knew, you would laugh less and cry more" 42 as a lesson. He takes his only guide, "the Prophet of Sorrow" 43 pbuh, as an example to himself. Doesn't he ever laugh, never smile? Of course, he smiles, he knows that a smile is sunnah and even charity ${ }^{44}$. However, he abstains to release himself and laugh out loud. He/she cries more than laughs. Why? Because, the people he/she took as an example had always cried all their lives. Prophets, saints, and righteous people. He sheds tears for not the inevitable things and the losses of the world but his sin, mistakes, faults, what he did not do when he should have done, even the sins of his friends and the troubles of all mankind. ${ }^{45}$ In this way, he can only keep his other principles alive. In this way, his heart becomes soft. In this way, he can live his mercy and compassion. Because these emotions are constantly found together as things that feed each other. ${ }^{46}$

\footnotetext{
$40 \quad$ See: $\quad$ http://www.herkul.org/kirik-testi/fedakarlik-olcusu-ve-infakta-denge/; http://www.herkul.org/tag/fedakarlik/; http://www.ozgurherkul.org/kirik-testi/fedakarlik-ve-adanmisruhlar/; and Gulen's sermon's topic was "Sacrifice" in city Afyon in 27 June 1980.

41 Bukhari, Azan, 36, Zakat, 16, Riqaq, 24, Hudud, 19; Muslim, Zakat, 91. See Tirmidhi, Zuhd, 53; Nasai, Qudat, 2; https://fgulen.com/tr/eserleri/kirik-testi/arsin-altinda-golgelenecek-yedi-zumre.

42 Tirmidhi, Zuhd, 9; Ibn Majah, Zuhd, 19.

43 Gulen, Fethullah, Key Concepts In Practice Of Sufism, Tughra Books, NJ, 2009, v. 1, pp. 29-32; http://www.herkul.org/tag/huzun-peygamberi/

44 Tirmidhi, Birr, 36.

45 See: Vakkasoğlu, Vehbi, Başkasının Günahına Ağlayan Adam, Nesil Publishing, Istanbul, 2005.

46 Gulen, Fethullah, "Gözyaşları", Sizıntı, September, 1979, Volume. 1, Issue 8; (Gulen, M. Fethullah, Çağ ve Nesil, Nil Publishing, Istanbul, 2011, p. 51);

http://www.herkul.org/tag/gozyasi/; http://www.herkul.org/tag/gozyaslari/.
} 


\section{Valuing Knowledge and Scholar}

The Golden Generation is always hungry for learning, keen on science and respectful to the scholar. He counts the day as lost when he doesn't learn anything new. For this, he reads, listens or watches something every day. It slowly fills the honeycomb of ma'rifatullah/knowledge in Allah. The more his ma'rifatullah increases, the more his muhabbatullah/love for God increases. $\mathrm{He} / \mathrm{she}$ always breathes the love. Over time, it becomes a means of indescribable flavors in his soul. With this inner power he works to be the best in his field. He sees this as a responsibility. He takes care that his education has two wings. While taking positive sciences on the one hand, he also gets his religious and moral education. Because he believes in this determination: "Light of heart is religious science and light of mind is science of civilization. Truth becomes manifest with the unity of both. With those two wings, the student's sense of effort flies. When they separated, it causes bigotry in the first, cheating and suspicion in the second." 47 Therefore, he believes that religion and science will never contradict, that there is a perfect harmony between the book of the universe and the Holy Quran. He/she also feels himself/herself compelled to study to a certain extent the positive sciences such as physics, chemistry and biology, which are used to read the book of the universe. On the other hand, he/she studies religious sciences in order to make the life of worship in a correct and healthy way, to make sense of life correctly, and to grasp everything in its original nature and accordingly that to gain the right perspective to his life. In every moment of his life there is either learning or teaching. This is the most important job in the world. He thinks that if there was anything more important than this, God would send the prophets with that job. ${ }^{48}$

\section{Gives Importance to Moral Values}

The Golden Generation exhibits exemplary behavior in all aspects. The reason for this is the importance it attaches to morality, a third aspect that completes belief and deeds. For, he is the ummah of a Prophet who says "I was sent to complete the supreme morality". ${ }^{49}$ He puts religion at the source of morality. Therefore, the examples of behavior of the Quran, Sunnah and al-Salaf al-Saliheen ${ }^{50}$ are the biggest sources. He believes that life can be lived in the sweetest way only by morality, and that living humanely depends on it. In accordance with the Prophet's statement "No father has ever given a child a gift that is superior to good manners", they try to convey their own acquisitions to the next generation. Therefore, the Golden Generation is not arrogant but modest, not selfish but self-sacrificing, not lazy but hardworking, forgiver not vengeful, benign not harsh, gentle not rude, organized not disorganized, disciplined not unplanned, does not act according to its mind but cares about consultation, not envious but proud of brothers' achievements, they are for reconciliation not resentment, generous not stingy, and exhibits many more good examples of morality. This is why, two Jordanian professors said when they saw this generation inside and outside Turkey, "none of their beard, robe and turban, but they live as companions." ${ }^{1}$ Another Moroccan professor said in response about the beauties he saw "There are many good and good things for humanity in this service movement. Because this movement is a truth that has emerged from a deep understanding that analyzes the Quran and Sunnah in depth. And at the same time, as we can see in the understanding of Fethullah Gulen Hojaefendi, this Hizmet Movement is the product of a deep historical consciousness...." 52 he said. Especially they are so sensitive about their chastity that they are very sensitive and strictly obey the orders of the religion so that nothing will

47 Nursi, Bediuzzaman Said, Munazarat, Prep. Abdullah Aymaz, Şahdamar Publishing, Istanbul, 2006, p. 125. 48 http://www.herkul.org/kirik-testi/gelecegi-insa-edecek-fikir-mimarlari/

49 Muwatta, Husn al-Khulk, 8; Ahmad b. Hanbal, v. 2, p. 381.

50 "al-salaf al-șālih" (السلف الصالح, "the pious predecessors") are often taken to be the first three generations of Muslims, that is the generations of the Prophet Muhammad and his companions (the Sahabah), their successors (the Tabi'un), and the successors of the successors (the Taba Tabi'in).

51 Two Jordanian academics (Dr. Sulyman Dagoor and Dr. Amjad Qourshah) made this statement after attending conferences related to Hizmet and meeting with service volunteers.

52 https://www.youtube.com/watch?v=IrFdZvo98tQ 
embarrass them and the Hizmet Movement ${ }^{53}$ in this regard. This is why even though millions of people have served in hundreds of countries in very different cultures and geographies, not a disgraceful job has occurred.

\section{Haram-Halal Sensitivity and Compliance to Rights}

The Golden Generation knows well that religion consists of haram and halal in a sense. That is why he sees committing "haram" as going into fire. He believes that the halal circle is very large, so there is no need to go into haram. Especially their sensitivities in the issue of human rights are remarkable. These people, who are trembling because afraid of to be unjust the rights of others, display exemplary behaviors in respect and conform to the public rights as well. For example, a Golden Generation working in the state does not go to the house with the state car allocated to it, but if it goes, it will pay for the gasoline. Because he received training of these moral values while he was growing up. Although Gulen served for more than two years in the military service among papers and pens but he did not write a personal line with the state's paper and pen. Although he was a guest in the dormitory or school he stayed, he paid the rent from his own pocket, even paid the rent of the hall used by those who came to visit him from his. Just as his father had tied his cows' mouths when he brought the without grazing because he was sensitive to the fact that if they eat it from someone else's field on the way, the milk would be haram for them. This lifestyle inevitably influenced his students and those who set their hearts on him. The generation that grew up with this discipline did not take bribes, do not take revenge, damage public property, or steal the property of others and the state.

The Golden Generation is a generation with many more features. For, their goal is to lead a life like the Companions of the Prophet pbuh, to contribute to humanity like them, and to be with them in the hereafter. ${ }^{54}$

\section{How is the Golden Generation Raised?}

The Golden Generation is only raised by another Golden Generation. The Golden Generation is actually the generation targeted by all prophets and entered into our literature as "futuwwah". For this reason, companions of our Prophet, who are the architects of the wonderful period of time called Asr-i Sa'adat (Era of the Companions: The Era of Happiness) and raised by the Prophet, are an exemplary Golden Generation. Therefore, the Golden Generation is an ideal generation. It is a generation that tries to reach the level of "perfect human/insan kâmil" which is the aim of humanity.

Education of this generation requires special effort, great sacrifices, patience and time. Just like our Prophet, who is a true human being, sallallahu alayhi wa sallam did. Above all, God educated Him. He said in one of his hadiths, "My Lord has disciplined me, how well he has educated me" 55 and eventually he became a guide for all humanity that will come until the Day of Judgment. He educated his companions, his companions educated his students called tabiin, then they educated atbau't-tabiin. Until now every generation gave attention to educate their generations. However last three centuries were very unproductive and unsuccessful centuries in raising ideal generation. For this reason, Muslims have suffered in every aspect of life in around the world during last three centuries.

Bediuzzaman Said Nursi was one of the prominent Islamic scholars of last century who dedicated himself to educate ideal generation. He focused to find the main and common problems

53 The Gulen movement (Hizmet in Turkish) is a worldwide civic initiative rooted in the spiritual and humanistic tradition of Islam and inspired by the ideas and activism of Mr. Fethullah Gulen. (https://www.gulenmovement.com/gulen-movement/what-is-the-gulen-movement)

$54 \quad$ See: http://www.herkul.org/herkulden-bir-demet-hadis/haftanin-hadis-i-serifi/; https://hizmetten.com/helal-lokma-ve-iffetli-nesiller/; http://www.ozgurherkul.org/bamteli/helal-haramhassasiyeti-ve-zehirli-lokmalar/.

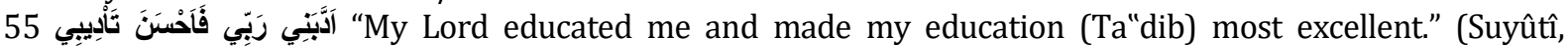
Jalalluddin, al-Jâmi' al-Saghîr, (Trans. To Turkish, Group), Yeni Asya Publishing, Istanbul, 2002, v. 1, p.113) 
of Muslims. For example, he underlined the six common problem of Muslims in 20. century in his "Damascus Sermon". "The sicknesses are these:

Firstly: The rising to life of despair and hopelessness in social life.

Secondly: The death of truthfulness in social and political life.

Thirdly: Love of enmity.

Fourthly: Not knowing the luminous bonds that bind the believers to one another.

Fifthly: Despotism, which spreads, becoming widespread as though it was various contagious diseases.

Sixthly: Restricting endeavor to what is personally beneficial."56

Then, he categorizes these problems under three main headings: Ignorance, poverty, and disunity or discrimination. Bediuzzaman not only identifies the problems, but also offers solutions for all of them. He said that discrimination can be solved with love and compassion, poverty with sharing, and ignorance can be resolved by art, education and alliance..$^{57}$

Bediuzzaman wrote down the plans for the solutions one by one and left. His life was not enough to bring all these ideas to life. However, with his works and lifestyle he showed how one can be a man of dakwa. He expected no benefit from anyone. He dismissed material authority and facilities. He lived out of desire, without gratitude to anyone. He devoted himself to raising ideal generation. But he passed away before he could see the fruits of the seeds he had planted.

After him Muhammed Fethullah Gulen has followed his footsteps and he also dedicated himself to educate the ideal generation to realize Bediuzzaman's dreams. He called them "golden generation/ideal generation/man of service/rabbaniyyun/devoteds/infatuateds of the time/fedayeen of love etc"

In his writings and speeches, he always talks about the characteristics of that golden generation. With these talks and writings, he draws the picture of new generation, gives principles, teaches the way of raising this generation. For example:

"Man of service must for the sake of the cause he has given his heart to be resolved to cross over seas of filth. When he has attained his object, he must be so mature that he will attribute everything to its Rightful Owner and be respectful and thankful to Him. His voice and each breath are spent in the glorification and magnifying of God the Sublime Creator. He holds everyone in high regard and esteem. He is so balanced and faithful to God's will that he will not turn into idols those whom he praises for their services. He knows himself first of all to be responsible and answerable for work left undone. He has to be considerate and fair-minded to everyone who comes to his aid and support the truth. He is extraordinarily resolved and hopeful even when his institutions have been destroyed his plans upset and his forces put to rout. He is moderate and tolerant when he has taken wing anew and soared to the summits. So rational and sagacious that he admits in advance that this path is very steep. So zealous persevering and confident that he can pass through all the pits of hell that he may encounter on his way. So faithful to the cause to which he has devoted his life that deeply in love with it he can sacrifice his life and all that he loves for its sake. So sincere and humble that he will never bring to mind all that he has accomplished."58

With these words he shows the main characteristics of ideal generation. Gulen started his service around 60 years ago. When he was young, he set out for this ideal. He started with middle and high school students. On the one hand, he taught them religious sciences and he gave them a perspective on the world as well. Gradually he tried to strengthen their faith first. He instilled in them the love of Allah and the love of the Messenger of Allah. Then, Islamic values penetrated their mind. While he was processing each value, he gave his examples from Allah's Messenger, his companions and Allah's friends (salaf saliheen). Thus, that value is fully understood. Besides, their respect for those great personalities was increasing.

He knew that the common solution of three basic problems was through education. What youth needs most is a role model. If you can't show them real role models, they'll find themselves

56 Nursi, Bediuzzaman Said, Hutbe-i Şamiye, (Risale-i Nur Külliyatından), Mega Publishing, Istanbul, 2000, p. 21. 57 Nursi, Bediuzzaman Said, Tarihçe-i Hayat, Şahdamar Publishing, Istanbul, 2014, p. 61.

58 Gulen, M. Fethullah, Ölçü ve Yoldaki Işıklar, Nil Publishing, Istanbul, 2011, p. 208. 
role models. These are sometimes a movie actor, sometimes a singer, sometimes a football or basketball player, and sometimes a youtuber. Sometimes they are likely to encounter bad examples, which means their destruction. That's why Gulen was the director of the Kestanepazarı Koran Course in Izmir, attending the children's classes and standing by them at the dormitory at night. He took care of their every need. He would get up at night and if someone's blanket opened while sleeping, he would cover him, and if there were little children who cried or missed their parents, he would talk with them for hours, calm them down and placate them.

He saw that education is the key solution. First, he made every effort to open religious schools by the state. He personally participated in collecting money from the public to open religious schools. He efforted in the dialogues necessary for statesmen to open these schools. Partially it also got results from this. But time showed him that the school in which the ideal generation will be raised should be different. These schools had to be a general school for everyone. Here, a very good modern education, foreign languages, and religious thought or morality should be given. The law did not allow to include religious courses in the curriculum. Therefore, in the dormitories, these children had to be helped by activities that would develop a firm belief, understanding of worship, love and respect, sense of responsibility, discipline, collective action, free thinking, courage and some personal abilities.

He understood that he needs two main group of people. One of them educators. Young, volunteer, dedicated, idealist youth. The other one is philanthropist, dedicated, sincere businessmen. When he taught young people and stimulated them with lofty ideas, on the other hand, he met with businessmen, gave speeches to them and instilled same ideas.

He used many tools to raise the ideal generation. He preached in great mosques such as Blue Mosque (Sultan Ahmad), Sulaymaniyah, Fatih, Hisar, Shadirwan, Kocatepe etc. Thousands of people attended these sermons. In this way, the love and enthusiasm of people who know the service were increasing. They were mingling with their brothers from all over the country. It was also possible for new people to come to these public sermons. Those who loved the atmosphere would buy the tapes of the speeches here and listen to them over and over again and make them listen to their loved ones.

On the other hand, he published a magazine with "Sizıntı" name. Academicians and teachers wrote articles here. He also wrote the editorial and middle article. In these articles, he always braided his ideal thoughts like a lace. This magazine was written in a popular style. He was trying to present the countless beauties created by Allah in the universe to the readers, that religion and science do not conflict, that Islam values modern science.

School and dormitories were another tool. Books are another one. By the way, he has around 80 books. Some of them are translated more than forty languages.

One of these books is "Çekirdekten Çınara/From the Seed to the Plane". In this book, he has written in detail how the "Golden Generation" should be raised.59 He starts from the very beginning that will be considered on the way to marriage. It emphasizes on the right choice of mate. He attaches importance to unity of ideas and ideals most of all. He then states that the engagement should continue for a while and that the characters should get to know each other in this process. He recommends that both parties act with the intention of strengthening their spiritual life and living a life that Allah is pleased with while entering this issue. In the meantime, he recommends that the basic rules of the religion should be observed and mistakes that would be considered haram should never be committed.

He then deals with the marriage and pregnancy process. He emphasizes that it is necessary to be sensitive about halal haram in this process. Emphasizes the importance of halal sustenance. Then, while speaking, he states that you should not backbite, not use lies and bad words, look at haram and listen to haram. In addition, he recommends doing as much as possible the beautiful things that the baby can feel even in the womb, such as salat, prayer, reading the Quran, and

59 By the way, in almost all of his works, the characteristics of this generation, the issues they should pay attention to and the issues they have to struggle with are included. 
listening to the Quran. After the child is born, he recommends naming, tahnik ${ }^{60}$, aqiqah ${ }^{61}$, circumcision etc. to perform the duties specified in the sunnah.

After that, he states that the parents' behaviors at home will nourish the child's subconscious. His/her character will be nourished by good things as he/she sees his/her mother or father as people who pray at home, read the Quran, cry from time to time, compassion and patience in actions. Gulen states that the age of 0-6 is very important for nurturing the subconscious. 62

Then comes primary, secondary and high school education. Here, emphasizing the triad of school, family and children, he states that the child should be developed all education and teaching and character development together. ${ }^{63}$

Big brothers (Abi) and big sisters (Abla) come into play an important role in high school and afterwards. They stay together in "Işık Evler/light houses"64 and go through a complete upbringing system. In these houses, he learns discipline, division of labor, cooperation, coexistence culture, problem solving skills, cooking, cleaning and many other things besides some religious knowledge.

Daily life in these houses is briefly as follows. All together they get up in the night and pray the salat tahajjud, read prays, and recite Quran. Then, the morning prayer and tasbihat/zikr and prays are performed together. After the tasbihat a short lesson is performed. In this lesson, each day of the week is followed by something different. For example, one day one of Bediuzzaman's books is read, one day one of Gulen's books is read, one day a fiqh lesson is given, one day a hadith lesson is given, one day they read the Quran, one day listen from Gulen's sermons, and one day they go to visit the neighbor "light house" for breakfast. Before the breakfast someone gives a lesson to all them. This lesson is done by the person who is a big brother at home, who has the most knowledge. Then breakfast is served. Next week the roles change and the visitors host them.

One person is on duty every day for breakfast and dinner. Thus, everyone learns to cook. Who has more experience helps in the newcomers' turn. After breakfast everyone goes to school. Anyone who does not have an important doing/duty outside has to return home on time. If someone has a doing and will come home late, they should tell their friends in advance. Because they usually eat dinner together and perform the night prayer (salat isha) and make lesson together like a family. Then they drink tea and chat together.

Meanwhile, everyone who stays at home has a duty to serve beside their school education. Some of them help their school lessons and teach voluntary mathematics, physics, and literature to high school students who come home, some keep the house accounting, some deal with mass shopping etc. There is a general cleaning of the house on Sunday. Everyone takes a place and cleans it until it is sparkling. These houses are not inferior to family houses.

There are certain rules for the continuation of order in this house. Discipline is very important. Cleaning, complying with the schedules of the house, coming and going home on time, and most of all, avoiding harmful habits. Unnecessary pursuits, bad habits and the relations with the people of the opposite sex are not allowed in these houses. Those who break discipline are warned. If he does not listen further, he will be punished with sent/driven out.

Furthermore, neighbors engage in constructive relationships with friends and relatives and invite them to pleasant activities. In this respect, they learn how to socialize. They learn to host guests, prepare catering and interact with people They are never the cause of conflict or fight They

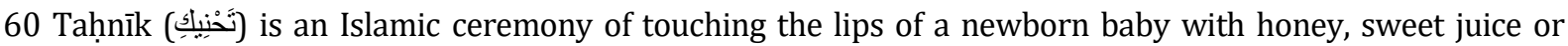
pressed dates. Originally the date was softened by mastication by the pious person and rubbed on the infant's palate. When his grandson Hasan was born Prophet Muhammad pbuh read the chapter of Ikhlas in his ear, gave it a date (tahnik) and named it. (Abu Dawud, Adab, 116; Tirmidhi, Adahi, 17)

61 Aqĩqah (Arabic:عقيقة), aqeeqa, or aqeeqah is the Islamic tradition of the sacrifice of an animal on the occasion of a child's birth. (Look: Nasai, Aqiqah, 1)

62 http://www.herkul.org/kirik-testi/cocuk-terbiyesinde-denge/

63 Gulen, M. Fethullah, Fasıldan Fasıla, Nil Publishing, Istanbul, 2011, v.4, p. 180.

${ }^{64}$ Gulen, M. Fethullah, Sızıntı, January, 1992. 
are representatives of safety and trust. In this way, they learn importance of the compassion for living and keeping alive. Because these issues are always emphasized in the books they read.

In the meantime, they organize reading camps to compensate for the inability to read more than the intensity of the classes in the school. Sometimes they camp for a week, sometimes two weeks, either in a summer house or in a hotel. Here they experience a spiritual atmosphere together. They do prayer, rosary and read lots of books together. They organize fun sports activities and competitions. Thus, they both relieve stress and recharge spiritually.

Another activity is trip. Once or twice a year, they organize trips to visit historical and touristic cities in other cities. However, they stay in a "Hizmet" institution or establishment where they go. They observe the services performed there on site. In this way, the trip is both cheap and the experience is exchanged. The strengthening of the brotherhood also becomes a bonus.

In addition, master-apprentice relationship is important in every aspect. People often see and learn from their master, expert and teacher what they cannot learn from books. This tradition continues in service as well. He/she will serve as a helper for a while with someone suitable for their future services, thus gaining experience. In this process, besides business skills and knowledge, they also learn the basic issues that a service person at all levels should pay attention to. Because those who act without a method, while doing it, demolish on the other hand. Hizmet has its own methods. For example, "human beings" is more important than anything else. In service, human beings are put at the center. Respect for human beings, not to be heartbroken, tolerate each other, working in harmony, determining boundaries in relations, small and large relationships, respect for values, respect for rights, the importance of working, not being idle, should not act without consultation, should obey the administrator in reasonable and legitimate matters, and He learns that he should never go outside the halal circle and many more.

In addition to the Golden Generation educators, there are also service groups consisting of tradesmen, businessmen, professions and women. Great importance is attached to their education as well. Weekly lectures, meetings and activities run together in collaboration with those in the field of education. In this way, everyone passes through the ways of upbringing we have presented above and devote their lives as a Golden Generation volunteer.

\section{How can We Protect the Golden Generation from the Expecting Hazards?}

Preserving the Golden Generation is as important and difficult as it is to raise it. Because their rivals and enemies are many and strong.

Therefore, there are some issues to be considered in the protection of this generation. It would be appropriate to mention a few of them only item by item.

1. Making use of spiritual sources of nutrition continuously.

2. Should go back and forth to service institutions and keep in touch. Never break the relationship or slow it down.

3. Everyone must have a duty. Being idle, spending time with empty things makes it difficult to maintain consistency. It becomes the devil's toy, and over time, intellectual shifts begin.

4. Visiting those who are righteous and sincere ones.

5 . Visiting to places with good services to get out of monotony and to share experiences.

6. Should discipline and plan his/her life.

7. Should try to reach them by setting small goals for self-improvement and more efficient service.

8. Should never read books or watch movies that are not recommended. They should definitely read the books and watch the movies that someone recommends. Because the life is short and books or movies are a lot.

9. Should not be alone. For, it is stated in the hadith that the friend of the person who is alone is Satan. ${ }^{65}$ When you are alone, the devil stimulates evil feelings.

65 Abu Dawud, Jihad, 79; Tirmidhi, Jihad, 4. 
10. Should do the works in consultation. Problems should be solved in consultation with experienced people. Thus, fewer mistakes are made. Morale deteriorates less and road fatigue is not experienced.

11. Reading, listening and watching especially motivational things.

12. For the friend who has the problem, the other friends should help solve his problem by intervening without wasting time.

13. Especially those who come to the age of marriage should be helped to get married

14. Besides, everyone is advised to choose a friend/partner for themselves. This friend is called "khayrkhâh". This friend is called "khayr-khâh". This person must be more knowledgeable, more loyal, more sincere, that he should authorize this person to warn him if he/she gets into a wrong doing one day. This friend acts as an insurance. Thus, he/she will also secure himself/herself more. The most important issue is the preservation of sincerity and brotherhood. Everyone from the Golden Generation does everything they do to gain Allah's sake. He constantly renews his intentions and strives to stay in the direction. The brotherhood that we call "uhuwwat" also helps this. Four people acting together, doing service division, helping each other and doing all their work with consultation do not work with capacity of three people, on the contrary, they work with capacity of 111 people. 66

\section{E. Golden Generation's Contribution to the Moderate Global Relations}

In this section, we will try to examine the reflections of the works brought forward by the Golden Generation we mentioned. First of all, as described, is there a Golden Generation today? In this section, we will try to examine some reflections of the works brought forward by the Golden Generation we mentioned before. Is there really such a generation? What do its services in the name of humanity or Islam?

Before giving some examples to show their services it will be fruitful to mention that the Golden Generation has endeavored to complete a righteous circle ${ }^{67}$ with other Hizmet institutions in almost every aspect of life besides schools. In this sense, the services provided by the "Abant Platform" of the Journalists and Writers Foundation have gained the appreciation of the whole world. In the first year, focusing to Turkey's problems, from all walks of different, almost every idea representative, academics, scientists, intellectuals, journalists, opinion leaders, religious leaders, and artists were invited to the platform. Everyone on the subject is set forth the effort to find common solutions. Conservative people attended these meetings, as well as representatives of socialist, communist, atheist, secular, Christian, Jewish and many other groups, and common solutions were sought for common problems. Later, these efforts reached a global level and experts were invited in America, Brussels, Moscow and elsewhere and efforts were made to meet common grounds and seek solutions to the problems of humanity.

On the other hand, "Kimse Yok mu" fraternal association has been targeted to the help and rescue the needy in Turkey or anywhere in the world. This association reached hundreds of thousands of poor families with food supplies in Turkey and after occurring disasters in countries such as Afghanistan, Pakistan, Indonesia, Colombia have launched an emergency relief campaign and have delivered aid to victims of disasters. In addition to bringing aid packages to many countries in Africa, they opened water wells in regions without water, built schools in places without schools, helped places with poor hospital or clinical facilities, came to the region with volunteer doctors and provided the treatment of patients, including surgeries. In this sense, the volunteer doctors from Turkey in Kimse Yok mu association's organization, bringing the surgical instruments has done thousands cataract surgery and has opened the eyes of thousands of people.

The power of the media today cannot be denied. Unfortunately, mass media institutions in Turkey have seen for years, has taken facade with lies and slander against Islam and Muslims.

${ }^{66}$ Nursi, Bediuzzaman Said, Lemalar, Şahdamar Publishing, Istanbul, 2014, p. 201.

67 In Turkish "Salih Daire" means all actions and institutions help each other. Because all of them for the same target and with same principles. Education, media, health sector, financial sector, helping hand organizations, dialogue organizations etc. 
Most of the owners of the world of press and television have been insulting, affronting and underestimating the religious people both in visual products such as news, movies and series, and in written products such as newspapers, magazines and books. They used to show the Imams as ugly, messy, lecherous, dishonest and deceitful. They have made fun of the people's belief. If someone from the Religious Affairs or someone has religious identity made a mistake, they would exaggerate their mistakes and attack them. Nothing that a teacher or a Muslim group does is shown beautifully. Tariqas and congregations were always under suspicion. Most of the time, lies were invented and desk reports were made against religious leaders. Turkish media history is full of countless examples of this. For example, the mufti's goat was stolen, the newspaper reported that "the mufti stole the goat." This was the product of an unprecedented rigid secular understanding. Therefore, it was necessary to exhibit a correct, honest and principled journalism and broadcasting. It was necessary to revive values in this field. Gulen knew the importance of media. That's why he advised Golden Generation to become media owners. First, a newspaper was bought for this. Its' name was Zaman and its' circulation was only 6.000. They worked a lot to be successful and it has become Turkey's largest newspaper with 1,000,000 circulation in 20 years. ${ }^{68}$ Television channels such as Samanyolu, Ebru, Mehtap TV and their education, culture and children sub-channels were opened. Again, Cihan News Agency was also established which was one of Turkey's most prestigious and accurate news agency. These institutions have always worked principled. They did not attack anyone's honor and dignity to make sensational news, did not demonize any institution or person, did not fake news, stayed away from obscenity and many things contrary to their values. This was very difficult. Because in this world, lies, slander, assault on personalities, and tears were common. The first years were very difficult. They stood with the help of some volunteer businessmen. However, the day came, they trained their own staff, produced quality products with their quality employees and gained the trust and appreciation of the whole country. This example is very attractive. One day, they invited a European expert TV broadcaster to the Samanyolu Television to supervise them. The man first studied the products made. Then he met with the general manager, director, screenwriter and reporters one by one. Almost all of them came from different professions. Some of them were teachers, some were preachers, some were engineers, etc. The man said in astonishment: "It is a wonder, people are wrong people, but the work done is right." 69

We will try to convey to you what these service people, who spread almost all over the world, have done and how these actions are beneficial in the development of international relations from the testimony of non-Hizmet academicians, journalists, statesmen, intellectuals, and writers.

In the last decade, many researchers about Hizmet, Golden Generation, and M. Fethullah Gulen wrote hundreds of articles and books. For example, Nikola Gruevski, who evaluated the service in general, says: "Fethullah Gulen has stated that society's three greatest enemies are ignorance, poverty, and internal schism (disunity) and inspired people to consider applying some practical solutions.

\section{Gulen's Solution for Ignorance}

Ignorance is the most serious problem, and it is defeated through education, which has always been the most important way of serving others. Fethullah Gulen has been encouraging people to serve humanity through education, intercultural and interfaith activities in formal and institutionalized efforts and projects.

For Fethullah Gulen Education is the most effective vehicle for change - regardless of whether it is in Turkey or abroad, and whether or not people have systems working or failing - as the solution of every problem in human life ultimately depends on the initiative and capacities of human beings themselves. Throughout his public life, Gulen has taught that learning is a duty for all humans and "by fulfilling it we attain the rank of true humanity and become a beneficial

\footnotetext{
68 https://tr.wikipedia.org/wiki/Zaman_(gazete)

${ }^{69}$ Deputy Vice President of Samanyolu Media Group told in a discussion with him.
} 
element of society". Gulen is not only addressing the education of children in his writings but the education of all. The participants in the movement see themselves as learning or attempting to learn all the time and the dominant theme of the movement is the struggle for self-improvement. Gulen's educational philosophy derives from his faith, and for him scientific and religious knowledge are essential and complementary parts of the same whole. Gulen movement participants support this synthesis of rational and religious knowledge. Consequently, Guleninspired schools value science and mathematics. Most of these schools have excellent computer technology and science laboratories...

To defeat ignorance through education, Gulen and his followers opened many colleges and educational facilities from Europe to Central Asia, from Africa to the Far East. These schools serve all people, regardless of their races, colors, or faiths. It is in these colleges; students of all cultures are taught universal values and ethics along with modern sciences.

\section{Gulen's Solution for Poverty}

In Gulen's thought poverty is mitigated through work and the possession of capital, justly deployed in the service of others. Fethullah Gulen encourages people to tackle with this problem in a larger scale and inspired people to from organizations like Tuskon and Kimse Yok $\mathrm{Mu}$ Association.

The Gulen movement fights poverty with Kimse Yok Mu Association, the main channel of aid and relief for the Gulen movement. Principle of Voluntariness executing the function of base of the Kimse Yok Mu association's working systems. All kind of aid activities as well as various national and international aid organizations distributions are carried out by volunteers of Kimse Yok Mu. Volunteers actively take charge in the process of all activities to be signed by the association, starting from planning until the implementation of it. Although Kimse Yok $\mathrm{Mu}$ Association began by striving to address the question of poverty in Turkey, their efforts quickly moved into the field of international aid and relief. After the underwater earthquake and resulting tsunami in the Indian Ocean that on 26 December 2006 devastated parts of Indonesia, Sri Lanka, India, and Thailand, and produced a death toll of over 128,000 people in Indonesia alone, Kimse Yok Mu was one of a host of international agencies that provided emergency relief and engaged in the effort at reconstruction of the region. Kimse Yok Mu undertook a campaign to raise funds for the affected regions and delivered clothing, food, and medicine to those who had taken refuge in camps, and provided chemicals to purify drinking water. The association funded repairs to houses and schools and reactivated a school destroyed by the tsunami. Kimse Yok Mu also helps the needy families delivering clothing, food, and medicine in Philippines, Pakistan, Ethiopia, Mongolia, Sudan, and Kenya. By 2007, aid programs administered by Kimse Yok Mu had reached 37 cities in Turkey and 42 countries around the world. Although the majority of these were in the Middle East, Asia, and Africa, Kimse Yok Mu has also carried out aid and relief programs in six European countries and in Peru in South America.

TUSKON's story started in the early 1990s by businessmen with social responsibility awareness and who are sensitive to country problems, forming associations in several cities. These associations were founded in order that little and middle-sized enterprises which form the mainstay of Turkish economy and also big and growing companies can develop themselves and expand to foreign markets in variable and dynamic economy. Tuskon launched its first foreign trade bridges conference three years ago, focused on African nations. Since then it has held similar events targeting the Asia-Pacific region and Eurasia. When the organization was approached to hold similar conferences with other regions, it decided to host the global trade summit open to everyone. Turkey's strategy of developing ties with African nations is paying off now that Turkish companies are suffering from the recession in Europe and its neighboring countries. Turkey World Trade Bridge 2009 conference held in Istanbul, Turkey, June 2-5. More than 3,000 Turkish businesspeople met with some 2,300 representatives of companies from 135 countries. Turkey's ties to Africa have resulted in the establishment of 12 African embassies in Istanbul, a three-fold growth since only a few years ago. 


\section{Gulen's Solution for Disunity}

Today, one of the most dangerous causes of disunity is ethnical-racist separatism. When the world is gradually becoming a small village, nations should come together and establish unity, and the universal targets appeal to people all over the world. This kind of disunity is difficult to understand. It is unnecessary and it is a dangerous behavior.

In Gulen's thought internal schism and disunity are vanquished by striving, through forbearance, tolerance and dialogue, for unity. For Gulen, dialogue, tolerance, and trust reinforce each other: tolerance is the acceptance of differences that arise from dialogue in order to further the wider goal of cooperation. Tolerance is based on the idea of charity, or love, and therefore is a duty to.

Gulen's approach: his vision of how the practice of tolerance of the other needs to be a component of one's own religious devotion. Gulen argues that the true marks of religion, as the connection between humanity and God, should be to benefit all people, not sanction discrimination and violence. Here he is at his most poetic when he connects the religious dimensions of love with the ethical obligations of tolerance and concern for the other. In Gulen's thinking there is no greater religious concept than love, there is no greater religious action than love: "Love is the most essential element of every being, and it is the most radiant light, and it is the greatest power; able to resist and overcome all else". True religion is therefore how we move from being merely human to in fact becoming humane. In this way, Gulen teaches, spiritual people are open to the flow of the divine.

In Gulen's thought, dialogue appears as a natural consequence of humanism. Mr. Gulen defines humanism as a doctrine of love and humanity. He warns against an unbalanced understanding of humanism, for instance one that misunderstands jihad and views non-Muslims as the antagonistic others. Gulen's humanism opposes a fanatical jihadist approach to humanity, and instead intends to actualize 'love of all humanity.' To Gulen, humanity is the most valuable being in the universe as the greatest mirror of God's names and attributes. Every human being is equally endowed with capacity to mirror divine nature and has the capability to be developed to an excellence greater than the universe. Thereby, first, all humans are equal as a mirror of God's attributes, irrespective of religion, race, wealth and social status. And second, since humans are created by the Creator's own love, love is the most essential element in humanity. These concepts of equality, love and humanity are the basis of Gulen's humanism, and serve as the founding principles of the Gulen movement."70

I think he summarized most of things in his article. I can add something to solution for poverty. Gulen encouraged charitable businessmen and women to provide scholarships, especially for poor children to be educated. On the other hand, in every school opened, the principle of having $15-25 \%$ scholarship children was introduced. It was recommended to build schools from the earnings of institutions such as Tuskon ${ }^{71}$, Bank Asya ${ }^{72}$, and Kaynak Holding ${ }^{73}$ to give scholarships to poor students. By opening reading houses in poor regions, hundreds of thousands of poor children were provided to come to these places after school and take courses in math, physics and chemistry. Thus, they were taught to fish instead of giving fish.

The service is available almost anywhere in the world today. However, within the framework of this article, it would be appropriate to look through the eyes of some researchers who have witnessed the services of the Golden Generation volunteers in educational institutions

70 https://www.fethullah-gulen.org/op-ed/three-greatest-enemies-ignorance-poverty-and-disunity.html 71 The Turkish Confederation of Businessmen and Industrialists (Turkish: Türkiye İşadamları ve Sanayiciler Konfederasyonu), best known by the abbreviation TUSKON, was an employers' organization in Turkey, with about 40,000 members. It was founded in 2005 by seven business federations. (https://en.wikipedia.org/wiki/Turkish_Confederation_of_Businessmen_and_Industrialists)

72 https://en.wikipedia.org/wiki/Bank_Asya

73 Kaynak Holding was a service organization that included many companies such as school supplies, book writing and printing, book sales stores, cargo companies, etc. Erdoğan seized the whole and appointed a trustee. Its' web page is under construction. 
that have been opened, especially in some ethnic, religious, social and economic problems, and to present some examples.

In Hizmet schools, education of tolerance is being practiced vividly and it is fair to say that diversity is part of their existent schooling system. In many countries, students from different ethnic, cultural and religious backgrounds study in the same peaceful atmosphere of these schools. For example, in Bosnia, Croatian and Serbian students-even though their numbers are small- study peacefully alongside Bosnian students, in spite of the brutal war. This is a powerful indication that the Gulen Movement's ${ }^{74}$ schools have succeeded in establishing a non-sectarian atmosphere in their educational system without neglecting to respect cultural and religious differences." 75

Hizmet had in Georgia, five high schools, five primary schools and one university in 2008. Golden Generation carried the same tolerance and common life development to there. There were 1800 students in primary and high schools, and 1000 students in the university at that time. Religious and ethnic structures were very colorful. There were children from 10 different countries: Muslim, Christian, Jewish, Azerbaijani, Armenian, Greek and Kurdish. Everybody could take good education at the same level without any discrimination. ${ }^{76}$

Iraq was a geography where great sacrifices were observed in general. Especially the Hizmet schools and establishments opened in the Northern Iraq Kurdish Region became an antidote to the ethnic and sectarian conflicts that were the biggest scourge of the region. In these schools, children from Arab, Kurdish, Turkmen, Chaldean, Christian, Muslim, Yazidi and Shiite groups received education with equal opportunities. The American congressman who came to visit this place visited these schools with a Hollywood movie star. They were so impressed by the landscape they saw that an example of world peace was standing before them alive. These schools played the role of a Noah's Ark in almost every aspect of their location. When the forces of Barzani and Talabânî clashed, the peshmerga took shelter in and found peace in these schools. ${ }^{77}$

Lawrence E. Carter, the dean of the martin luther king Jr. International Chapel, has said Turkish-Islamic scholar Fethullah Gulen is part of a struggle for peace across the world through the activities inspired by him.

The professor stated that Gulen is among "great personalities" like Daisaku Ikeda, Nelson Mandela and Martin Luther King, who are deeply committed to Mahatma Gandhi's philosophy of peaceful resistance and strongly reject violence.

When responding to a question of why Gulen was selected for the 2015 Gandhi King Ikeda Peace Award, Carter said he looked for a "peace envoy" in the Muslim world for 15 years and he finally came across Gulen, whose teachings have reached to 192 countries across the world. He said they decided to give the award to Gulen, who was the first Muslim to condemn the Sept. 11 attack in $2011 .{ }^{78}$

Prof. Carter attends a program at the Nelson Mandela Foundation on his visit to South Africa, and after explaining that Hizmet people act in a similar manner as Martin Luther King responded with tolerance and gentleness to harshness and sorrow, someone said, "It's easy to talk about the theory but very difficult to educate, especially against drugs and bad habits... ". Prof. Carter says: "What I'm talking about is not theoretical." He then summons three Hizmet volunteers

\footnotetext{
74 Western researchers call this movement as "The Gulen Movement". But Gulen does not accept this. "Because it would be injustice and unfair to mention so many good things done by millions of service volunteers in my name. I do not even do one-millionth of all these good services and I do not know most of the millions of volunteers. If this movement is to be tried, it should be called "Hizmet/Service" or "Volunteers Movement" he says. (Gulen, M. Fethullah, Kırık Testi, Nil Publishing, Istanbul, 2011, v. 1, pp. 104-108)

75 https://fgulen.com/en/fethullah-gulens-life-en/the-art-of-coexistence-pioneering-role-of-fethullah-gulenand-hizmet-movement/the-hizmet-movement-and-its-contribution-to-the-global-peace-and-tolerance 76 Mercan, Faruk, M. Fethullah Gülen: Allah Yolunda Bir Ömür, Süreyya Publishing, Canada, 2019, p. 338. 77 Mercan, Faruk, Fethullah Gulen, Doğan Kitap, Istanbul, 2008, s. 274.

78 http://fgulen.com/en/press/news-en/todays-zaman-us-professor-carter-fethullah-gulen-struggles-forpeace-against-poverty-and-terrorism
} 
to the stage. First one was Ayhan Çetin Bey. He was one of a Hizmet volunteer who had been serving in South Africa many years told the striking story of Nicholas Bixa.

Nicholas Bixa was from a family of 9 children in Soweto, where only blacks lived, whites could not enter, and the crime rate was high in Johannesburg. Police killed two of his brothers in the bank robbery. Two older sisters died in a traffic accident. His two brothers were in prison. One day, two teachers came to Soweto, which was not visited by whites except the police. "When they came, we said, are these police or soldiers? They said they were teachers. They tested 150 students." Nicholas was saying. Two teachers were coming from the newly opened Hizmet school. Nicholas was one of the 150 students who took the exam. They enrolled 26 students. Nicholas was taken to the dormitory, but he escaped from the dormitory and returned to the village. A few days later the teachers came to the village again. They were insistently inviting Nicholas to the school. In that time Nicholas was not at home and the teachers almost two hours waited him in his house with non-speaker English mom. Nicholas didn't want it, but his mother pleaded. She said "Go to school for me. Look at the state of your brothers" and she cried. He came back to the school in order not to upset his mother. This time, both the school and the dormitory started to look more cute to him. After a while, he stopped running. After graduation he went to college in Turkey. When the university was over, he turned and became a biology and physical education teacher at the school he graduated from. Then he became the director of the dormitory. One day she brought her mother and showed her school. Her mother's tears of happiness were his biggest reward.

The second person who came to the stage was a businessman. This Turkish businessman named Vuslat, who came to this country 15 years ago, devoted his life to service and spent a significant part of his money on service activities here. Thirdly, there was a friend who migrated here while he was at the head of the cultural center in the city of Atlanta in America and he also gave information about the dialogue activities in America. Carter had the last word: "As you can see, I'm not talking about theory. Look at these people. They open schools all over the world, help the poor, organize programs in the name of peace. They are realizing what we talk about."79

Doctor Frene Ginwala, who was the first female Parliament Speaker of South Africa, said: "Whatever nation has come to South Africa so far has come to get something from here, including us. This is the first time these people (Golden Generation) have come to give something to our people." Ginwala was a South African of Indian descent. 80

Ambassador David Shinn says the following about the Hizmet schools opened in Africa and their function: "For 60 years I have had dreams of a world of peace. If Eastern, Western, Northern, Southern, Black and White embrace each other... I have always longed for it; it has always been my dream." While saying these, he stated that his dream came true thanks to Hizmet schools. Ambassador Shinn has also written a book about his Service in Africa. Prof. While describing this book, John Esposito said, "Many books have been written on the Movement, but Ambassador Shinn has also written a book. Readers will find golden information about Hizmet's education network, social activities, humanitarian aid and dialogue efforts in Africa". 81

"When we wanted to send our children to the best school in Madagascar, they recommended a school run by the Turks/Hizmet" said a wealthy French businessman living in Madakascar, talking about Hizmet schools. ${ }^{82}$

Ethiopian Minister of Federal Affairs Shiferaw Tekelemariam said "At these schools, where there is a multicultural structure, the understanding of living together is promoted despite differences. The biggest problems of today, such as discrimination, conflicts and radicalism, are discussed at these schools" 83

79 Mercan, ibid, (2019), pp. 294-297

80 Mercan, ibid, (2019), p. 297.

81 Mercan, ibid, (2019), p. 319.

82 Mercan, ibid, (2008), p. 272.

83 http://fgulen.com/en/press/news-en/today-s-zaman-hizmet-contribution-to-global-peace-discussed-inaddis-ababa 
The representatives of the Golden Generation, who opened schools in 49 countries of Africa, were struggling, sometimes under very difficult conditions, sometimes with diseases, and sometimes in impossibilities. Sometimes they faced life threatening. For example, Boko Haram was not satisfied with the school opened in Nigeria and they came to the village $1.5 \mathrm{~km}$ from the school and massacred more than 150 people. The school was protected by high walls. The teachers lived in the school. However, they were going to the city every two months. ${ }^{84}$ Facing such difficulties in Somalia, the Golden Generation also sacrificed two of their teachers who were martyred by terrorists who blocked the road here. 85

The example in the Philippines tells the whole world something important. Thomas Michel, Secretary General of Interfaith Dialogue Council in Rome, Italy, visited the Turkish tolerance schools in 1995, in Zamboanga. "The Turkish and Filipino staff's proud claim was a stunning reality for me as Muslims and Christian students were getting education with true spirit of a culture of dialogue and tolerance," Michel shared these remarks with gatherings around the world. ${ }^{86}$ Michel sees that especially in this school, which is opened in the region where there is a Muslim-Christian conflict, children from both religions receive education, but the conflict between the people is not seen in the school, and the students and teachers focus only on education in peace and harmony. Finally, to express the peace atmosphere in the school "This school has become a "peace island". How much do we need such islands of peace in the world" he says. ${ }^{87}$

Another example is from Cambodia. A mother who gave her child to a Hizmet school said, “Please don't take my son out of school. Since I lost my husband, my son used to beat me every evening when he came home, but after he came to your school, he did not beat me.88

Even Turkey, the cradle of Hizmet... Due to the problems it has, it is one of the countries that need the Hizmet the most. Maybe because of His mercy Allah gave opportunity to start Hizmet there first. Turkey, which housed the Ottoman balance, so many of race, religion, language and culture is a country with a mosaic of sects. In the last quarter century, the Turkish-Kurdish and Alevi-Sunni conflict has been fueled by certain outbreaks, and it is aimed to damage the peace and security in the country. Because, in such mixed environments, the agenda will always turn on these two issues, some circles will profit from these conflicts, and some will do their secret and deep affairs more easily.

For example, Turkey has e terrorism problem in East and South East of Turkey. This is one of the biggest problems of it. The state does not treat the Kurdish people warmly. Education is paralyzed. Job opportunities are very few. Cities are underdeveloped. Hospitals are insufficient. Investors, teachers and doctors do not go to the region due to terrorism. Since the quality of education is low, the rate of children attending university is low. The people of the region, most of whom are Kurdish, are poor and uneducated. Military intelligence exerts pressure on people in the region. Illegal organizations are also putting pressure on the people as well. The people are caught between the oppressing state and the terrorist groups that are fighting for their rights socalled. However, Gulen encouraged the civilian population to implement the recipe offered by Bediuzzaman. Unfortunately, the state's wrong actions in solving this problem and its inability to put forth a strong and prudent pushed Hizmet to struggle almost alone in the region. Saying that everything should not be expected from the state, Gulen encouraged the volunteers of the Golden

84 Mercan, ibid, (2019), p. 319.

85 See: Mercan, ibid, (2019), p. 319.

86 Esposito, L. John, Ihsan Yılmaz, İslam ve Barıș İnşası: Gülen Hareketi İnsiyatifleri, Nil Publishing, Istanbul, 2004, p. 226.

87 https://fgulen.com/tr/basindan-tr/haberler/Zaman-Turk-Okullari-Dunya-Genelinde-Baris-Adalari-Gibi 88 Mercan, Fethullah Gulen, s. 274. 
Generation to serve there, despite the $\mathrm{PKK}^{89}$, which is engaged in terrorist activities in the eastern region of the country, in other words, despite the problem of safety of life and property. ${ }^{90}$

With his persistent encouragement, a great educational activity started in the eastern regions, hundreds of teachers voluntarily served in that region, schools were opened, dormitories and nurseries were established. It was even encouraged to provide scholarships to poor children in schools and to establish reading houses in places where those who could not attend schools. Young people in this region were protected from falling into the arms of the PKK by channeling them to education. This was the biggest blow to terror. The observations of Mehmet Kalyoncu, who conducted research in the region, are as follows:

Despite the fact that there has not been any major conflict between the Muslim and nonMuslim communities in Mardin since the turbulent era of World War I, the peaceful relations between the Assyrians and the Muslim Kurds and Arabs have lately been internalized by all parts of the local society. An Assyrian man in Mardin told me that "up until [prominent Turkish Islamic scholar] Fethullah Gulen and the Journalists and Writers Foundation started the interfaith dialogue process in the mid 1990s, people around us used to merely view us as "unbelievers,' just like [they refer to] the Yezidi. But after Gulen initiated dialogue with the Christian and Jewish leaders, people started to respect us as "People of the Book.

Another Assyrian, Mr. Kolda, owns a bookshop in upper Mardin. "Fifteen or so years ago," he told me, "my friends and I were still being discriminated against by our classmates due to our Christian identity. They were calling as “Gavur' or 'unbeliever.' But since then, things have started to change."

In a similar vein, Mr. Gulten, the Head of the Midyat Assyrian Foundation, stressed that "Gulen's tears have been a shield for us here," referring to Fethullah Gulen's highly emotional public addresses which were marked by his own tears and calls for accepting people of different religions. Both the Assyrian Metropolitan and Mr. Gulten noted that the Interfaith Dialogue event organized by the Journalists and Writers Foundation a year ago at the historic Kasimiye Madrasa has dramatically changed the perceptions of the local people about the Christians in Mardin for the better. Several other Assyrians in Mardin also told me that the renowned Muslim scholar has initiated a process which cultivated new mutual understanding between the Muslims and nonMuslims in this corner of Turkey.

My recent experiences in Mardin reaffirmed my belief that Turkey should recognize that its minorities, such as the Assyrians, are the nation's very own people. As Gulten notes, they have fought to defend Turkey in the past, continue to serve in its military, and pay their taxes just like all the country's other citizens. In reality, they are more Turkish than British, French or Greek, Dutch or German or whatever else. However, Turkey's relative neglect in failing to address basic needs that stem from their religious identity has led them to sympathize more with the Assyrian diasporas in various countries in Europe and with their respective political circles." 91

One of Hizmet volunteer Bahattin Karataş gives some info about the Golden Generation's services in the region. "With the "Reading Halls Project", which has been implemented since the early 2000s, I can say that there is almost no point left until the most remote corners of the region. For example, 830 students were reached in Şemdinli92; As of 2010, a total of 220 thousand Kurdish children in the East and Southeast received free education and service in these institutions.

89 Kurdistan Workers' Party/Partiya Karkerên Kurdistanê: The PKK's ideology was originally a fusion of revolutionary socialism and Kurdish nationalism, seeking the foundation of an independent communist Kurdistan. See: https://en.wikipedia.org/wiki/Kurdistan_Workers\%27_Party $90 \quad$ http://www.herkul.org/tag/kurt-meselesi/; https://www.turkishnews.com/tr/content/2011/11/15/gulenin-kurt-sorununa-cozum-yaklasimi-pkkyipanikletti/; http://fgulen.com/tr/basindan-tr/dizi-yazilar-dosyalar/ozel-dosyalar/fgulen-com-kurt-meselesive-cozum-recetesi; http://www.herkul.org/herkul-nagme/504-nagme-yangin-o-recete-ve-gaflet/.

91 http://www.balkanalysis.com/blog/2006/03/09/conversations-with-the-assyrians-of-mardin/; See: Kalyoncu, Mehmet, A Civilian Response to Ethno-Religious Conflict: The Gulen Movement in Southeast Turkey, The Light Inc., NJ, 2008.

92 A town of city Hakkari in East of Turkey. It is in the border of Iran and Iraq. 
Thousands of doctors, engineers, judges, prosecutors, teachers, etc. the profession was trained. These people who grew up now serving their region and people. In addition, the first foundation university named "Selahaddin Eyyûbi University" was established in Diyarbakır in the east, which includes the curriculum and program that will be the infrastructure for Kurdish language education in the future. Undergraduate and postgraduate education and training in the Kurdish language were also among its curricula. This was a first in Turkey." 93

The following example also sheds light on another big problem of Turkey. There was a villa complex in Istanbul where about three hundred luxury villas were built. It was in a very nice location. Government officials, especially the Minister of Forestry, appeared in the news, declaring that this structure was illegal and that they would fight against them. The main purpose was to take that place from its owners. Because the location was very important. The government filed a lawsuit. The owner of the complex sent one of his employees to the judge of the case and gave him a check to give a bribe to the judge. It was $\$ 10,000,000$ on the check. The man went to the judge, He explained the sensitivity of the subject and asked for help. He handed the check to the table. The judge looked at the guy sternly and threw the check into the man's face. The man was scared, and without further ado, he turned to his boss and explained the situation. This time the boss came with a checkbook. They thought that the judge did not like the amount. The boss spoke imploringly, that he had invested all his fortune here, that he had already sold the villas but that they had the government in front of them, begged him to help him, and he wrote $\$ 20,000,000$ on the check. He was afraid of the loss of this wealth of 300 villas at 2 or 3 million dollar each. The judge looked at the man thoroughly and said: "I have examined your documents. The land is taken duly, the permits are complete. There is no lawlessness. You will probably win the case. It doesn't matter if the state is opposer of you..." and handed the check back. The man was in shock. He did not know whether he should laugh or cry with joy. Then he woke up and said, "Sir, please accept this little gift." The judge suddenly became serious, "As for it, I can't take it" said. The man was very surprised, that is how things usually work in his world. "Why, Sir?" The judge answered, "Because I was not educated that way." The boss asked with astonishment "Who did educate you?" Judge said that he stayed in Hizmet's dormitories and read the books they read. ${ }^{94}$

At this point, it comes to mind to ask who would not want to have such educated judges, prosecutors, teachers, civil servants, soldiers, policemen, politicians, merchants, vendors, employers, employees, etc.

Hizmet volunteers opened many institutions in Balkans. Especially example of Bosnia is very interesting. Bosnia was in a great war in the 1990s. Serbs and Croats attacked Bosnians; serious civilian casualties were inflicted. While the war continued under the siege of Sarajevo Hizmet volunteers came from Turkey. The only way to enter the city from the outside was a tunnel one and a half meters high and 800 meters long. When Bosnian soldiers saw civilians coming to this tunnel, they asked why they came and were very surprised at the response they received from them: "to open a school". They had books and supplies on their backs. These training volunteers starved there for about three days and passed out. When the war ended, the officials who believed in the sincerity of these young people told them that they could use a destroyed building as a school. Journalists and Writers Foundation organized a special match between the National Football Team of Turkey and a mixed world team. Gulen also watched this match with Maradona in the stands. The proceeds of the match were sent to the construction of the school in Bosnia. In this way, both the expenses of the school were paid and the attention of the world public opinion was drawn to what happened in Bosnia. ${ }^{95}$

Bosnian Prime Minister Prof. Zlatko Lagumdzija expresses his experience with this school as follows: "I saw that the program in this school was superior to our schools. It was a global

http://thecrcl.ca/misafir-yazar-bahattin-karatas-hizmet-hareketinin-dogu-ve-guneydoguyakazandirdiklari/; $\quad$ https://www.tr724.com/omrumu-ulkem-bolunmesin-milletim-kamplasmasin-diyevakfettim/ 94 Taken from a chat with a media manager. (Writer) 95 Mercan, ibid, (2019), pp. 305-306. 
school; it was high quality and it had an English program. I would leave my child and pick it up at noon, I didn't have to worry. He has a perfect philosophy. He gathered successful students from all over the country and gave scholarships, and children of families like us who gave money competed with them. My son came home one day. He asked me to contact the school administration for the expenses of a female student going to the singing Olympics in New York and open a charity campaign. The child may be a very good economist, good engineer, but being a good person is very important. This is a big win for the country. I saw this on my son. In this school, students do not ask about each other's ethnicity and religion. The kids know who they are. Their identity is valuable, but they learn to appreciate the identity and belonging of others... Teachers treat students like their parents. My children see their teachers as members of the family. Being open-minded, students were taught this. If teachers are not open-minded, they cannot teach this." 96

Sarajevo University Dean Zühdü Hasanovic said, "With this education system, Hizmet is raising such people that they understand and respect others... People stayed away from each other after the war... Hizmet brought people together. Therefore, more schools should be opened here. Also in the Croatian and Serbian regions..."97

The son of former Foreign Minister of Albania Besnik Mutafaj was also graduated from these schools. He points out that his son has a law degree in France and that he and his friends are very good citizens. He says that these young people are educated in England, Holland, France and Italy and they are very open-minded. "This generation is not just better quality. They have more free spirits... Many Albanians have been educated in Qatar, Yemen, Sudan, Egypt. They are open to radical trends. Previously, Salafists came and opened madrasahs. But Albanian Muslims see themselves as European and want integration with Europe. There are Christians and Muslims in these (Hizmet) schools... They learn to know each other and to respect each other. This meeting and dialogue process with Islam take place in a very natural environment. These young people show that Islam is a religion of peace."98

Problems encountered in eastern Turkey, taking place in Afghanistan is even likewise experienced in many parts of the world. If a child living in this geography gets a good education, he / she can get the chance to get education and save his life in developed countries of the world. When he is saved, he can also help his family, environment and country. Otherwise, there are not many alternatives. It will most likely struggle to survive amid impossibilities and adopt the bigotry, radicalism and even the understanding of terrorism produced by ignorance. Thus, it will take its place in the society as a potential problem. Therefore, education, especially the Golden Generation training targeted by Hizmet volunteers, is like oxygen for this geography. Thousands of Afghan young people graduating from the schools opened here today speak at least three languages and strive to contribute to humanity by having a good education. Yes, schools of Hizmet in Afghanistan were opened with the efforts of the Muhajir-spirited Golden Generation, who came to this country with their families during the conflict between the Taliban and Rashid Dostum, who carried out educational activities here at the expense of their lives and said, "Wherever I die, bury me in Afghanistan." These schools became so popular that 15,000 students applied to the school that only had 600 capacity. Approximately 5,100 students graduated from these schools, which gave their first graduates in 2000. To read universities, they had gone to 41 countries, including Germany, America, Canada, England, Turkey and India. Of these, 402 studied law, 918 medicine, 1263 engineering and 887 economics. ${ }^{99}$

Professor of Geneva University, who visited the Hizmet schools in Mongolia. Pierre Montandon: "I saw a Switzerland in the middle of the desert there. This professionalism comes from Turkey's historical and cultural heritage ... If these colleges opened while Europe is

96 Mercan, ibid, (2019), pp. 306-307.

97 Mercan, ibid, (2019), pp. 308-309.

98 Mercan, ibid, (2019), pp. 315.

99 Mercan, ibid, (2019), p. 329. 
experiencing the influx of Turkish workers had begun in the 1960s, today Europe would be dependent on Turkey."100

When the first Hizmet college was opened in Moscow in 1995, the Russian education official said: “There are two important events in Russia's history. One is Gagarin's travel to the moon, the other is the opening of a Turkish school in Moscow."101

Likewise, the senior Russian officer who lives in Kyrgyzstan and sent his child to Hizmet school here said: "Historical hostilities are behind. The world is changing. I follow these schools. I want my child to also benefit from the quality education and training system here."102

The number of schools that started service in Pakistan in 1995 reached 13 and the number of students in time reached 3,000. For their success, President Pervez Musharraf gave these schools the "Sacrifice Award", the highest order of the Pakistani State.103

Another striking example is that sentences in an interview with the New York Times by a Pakistani who sent his brother to these schools: "Two brothers from my tribe died as suicide bombers. My brother, as a true Muslim, will approach people fairly and wisely, not intolerance."104

Another Pakistani who gave his children to these schools said, "I thought America or the West was behind every failure of us. I have now learned that the real problem is within us." 105

A Western writer also says: "There is still cannibalism in Papua New Guinea, there are people eating people. I don't even go there as a tourist. But the Turks went there to open a school"106

Yes, those who set off with this devotion and sincerity, none other than the Golden Generation representatives who pioneered the raising of a generation that won the third place in the world science Olympics from Yemen, where Ladens originated. ${ }^{107}$

The world-famous Kyrgyz novelist Cengiz Aytmatov commented: "These schools will be the antidote to terror, the troublemaker of the global village (the world)". 108

These volunteers, who opened schools not only in second or third world countries but also in modern western states, were successful there as well. For example, it was reported in the French newspaper Le Monde on 21 January 2008 that Hizmet schools are successful in the German system. ${ }^{109}$ Likewise, Hizmet schools in Pakistan were made to the headline of the New York Times on May 4, 2008.110 A Charter School in Tuscon, Arizona where Hizmet volunteers work, was also a first ranked school in the state only in six years.111

Reymond Kelly, Chief of the Police Department of New York City, said "The Turkish community gives a positive synergy to this city" while visiting the "Amity School" opened by Hizmet volunteers and meant Hizmet volunteers. This school won 28 medals at the New York State Science Olympics in 2007 alone. ${ }^{112}$

Nazlı Ilıcak, a journalist with years of experience, expresses the Western approach to Hizmet schools as follows according one of her exprerience: "We first came together in the House of Lords. At the meeting organized by Lord Ahmet of Rotherham, we listened to speeches from British

100 Mercan, ibid, (2019), p. 339.

101 Mercan, ibid, (2008), p. 272.

102 Ibid.

103 An earthquake disaster occurred in Pakistan in October 2005. After that, a big aid campaign was started with Gulen's call. Millions of dollars in aid were handed over to President Pervez Musharraf himself in Pakistan. Such aid campaigns initiated by Gulen have also been carried out after the 2004 earthquake in Indonesia, then the hurricane in Burma and the earthquake in China. (Mercan, ibid, (2008), p. 273)

104 Mercan, ibid, (2019), p. 333.

105 Ibid.

106 Mercan, ibid, (2008), p. 273.

107 Ibid.

108 Mercan, ibid, (2019), p. 322.

109 Mercan, ibid, (2008), p. 273.

110 Ibid.

111 From interview with the director of school in 2006.

112 Mercan, ibid, (2008), p. 274. 
politicians and scientists expressing the role of Fethullah Gulen in the understanding of Islam; then, in the halls of two prestigious education centers, the first, the University of London (SOAS), and the second, the London School of Economics (LSE), we discussed the same subject, "Thoughts of Gulen; his contributions to world peace; whether it will be possible to create a new European Islamic identity; we have discussed the "interaction between liberalism and Islam". "Is Islamic identity in harmony or in conflict with modernization?" We sought an answer to the question. Those who are curious about the details of the 750-page English papers can reach them at www.gulenconference.org.uk. I will continue to convey my impressions.

I came across the representatives of those whom Fethullah Gulen called the "Golden Generation" in London. They speak English like their mother tongue; they show the utmost courtesy and respect. Thanks to this new generation, schools opened all over the world can be so successful; foreign counterparts are affected in mutual contacts. Several schools have also been opened in London. Each school acts as an 'anchor' to hold onto the land, and other activities develop around the schoolhouse. For example, I witnessed that the British who visited the schools appreciated the level of education as well as admired the adherence and decency of the young people who grew up there. When the teacher or visitor enters the classroom, the students stand up, raise their finger to ask questions, etc. all these were in conservative English behaves but they lost. Also, they were surprised at the motivation of the parents of the children who study in schools. Not the brothers of "Hizmet" or the young teachers of the "Golden Generation", but also parents are in a total mobilization. Is it possible not to achieve success in a job that you do with such deep sincerity, putting your heart, love and of course your prayers?

With its constructive, peaceful, tolerant and open to dialogue features, the Gulen Movement positively affects everyone it comes into contact with. That is why, in the halls of the world's most prestigious universities, faculty members from renowned universities talk about the "Muslim world and the role of the Gulen Movement in development". ${ }^{113}$

\section{F. Conclusion}

The Golden Generation is not reserved for just one nation. The Golden Generation is a generation that all humanity has been waiting for, looking for, and dreaming of. The solution to the main problems of all mankind, to make laugh who is crying, to save who is oppressed, the establishment of world peace, recognizing and protecting the environment and nature as a trust from Allah, giving the necessary value to human and making the world a livable place depend on the raising of this generation. This generation is a precious generation that will treat everyone on the basis of being "human" regardless of religion, nation, race, sect, color, economic status or some other positions. It is a generation that will love the creation because of its Creator.

When this is the case, it is necessary to know well who the Golden Generation is, its purpose and what it does. If this is well known, the whole world will roll up their sleeves to raise its own golden generation, and will spend all its wealth on this path. Because this is the only way you can look to the future with hope. Otherwise, if cruel, machiavellian, egoistic and selfish generations steer the future, the result will be disappointment. A world full of conflicts, fights, wars and betrayals will wait for us. The world can no longer tolerate great wars. People are also tired of fighting now.

So, our duty is to strive for the growth of the Golden Generation. It is also necessary not to sacrifice this generation, which has grown up with great difficulties, to daily politics, interests, party and faction fights, racism and ignorance. In order to protect them, we must stand by them, support them and open their way. Because this generation has so far demonstrated through their lives that they have never had criminal crimes that would embarrass anyone, they did not engage in any terrorism, they did not have narcotics crimes, they did not commit lecherous crimes, they did not have any disgraceful crimes. They don't even have bad habits like smoking. However, the

113 https://fgulen.com/tr/basindan-tr/kose-yazilari/Nazli-Ilicak-Sabah-Hizmet-ve-Altin-Nesil 
tyrants, and oppressors will not think a second to spend them like coins for their own political ends. I think it is our duty to keep humanity vigilant about this issue and to protect this generation.

\section{References}

Abu Dawud, Sulaiman b. al-Ash'ath al-Azdi al-Sijistani, Sunan, Riyadh: Dar al-Salam, n.d.

Ahmad b. Hanbal, Abu Abdillah Ahmad b. Muhammad, Al-Musnad, Istanbul: Kahraman Publishing, n.d.

Bukhari, Muhammad b. Ismail b. Ibrahim b. al-Mughirah, Jami' al-Sahih, Riyadh: Dar al- Salam, n.d.

Carrel, Alexis, Man the Unknown, Harper \& Brothers, 1939.

Esposito, L. John, Ihsan Yılmaz, İslam ve Barış İnşası: Gülen Hareketi İnsiyatifleri. Istanbul: Nil Publishing, 2004.

Gulen, Fethullah, “Gözyaşları”, Sızıntı 1, no. 8 (September 1979).

. Pearls of Wisdom, Tughra Books, New Jersey, 2007.

Yenilenme Cehdi, Kırık Testi-12, "Adanmışlık Ruhu ve Hayat Standardı". New Jersey:

Blue Dome Publishing, 2016.

Advocate of Dialogue, Compiled by Ali Unal, Alphonse Williams, Fountain, 2000.

Emerald Hills of the Heart Key: Concepts in the Practice of Sufism, v. 2. New Jersey:

Tughra Books, 2011.

- Key Concepts in Practice of Sufism, v. 1. New Jersey; Tughra Books, 2009.

. Prizma-3, 6. Version. Izmir: Nil Publishing, 1999.

Toward a Global Civilization of Love \& Tolerance. New Jersey: The Light Inc., 2004.

Key Concepts in the Practice of Sufism: Emerald Hills of the Heart. New Jersey; Tughra Books, 2009.

---------. Buhranlı Günler ve Ümit Atlasımız, “Gaflet ve Ülfete Yenik Düşmemiş Dua”. Izmir: Nil Publishing, 2015.

C Cağ ve Nesil. Istanbul: Nil Publishing, 2011.

Fasıldan Fasıla. Istanbul: Nil Publishing, 2011.

Kirlk Testi. Istanbul: Nil Publishing, 2011.

Ölçü ve Yoldaki Işılklar. Izmir: Nil Publishing, 2011.

. Yitirilmiş Cennete Doğru. Izmir: Nil Publishing, 2011.

Haylamaz, Reşit. Gönül Tahtımızın Eşsiz Sultanı Efendimiz sallallahu aleyhi ve sellem. Izmir: Işık Publishing, 2007.

Ibn Furak, Abû Bakr Muhammad b. Hasan, Al-Mujarrad fî makâlât-ı Abî Hasan al-Ash'arî. Cairo: Maktabat al-Saqâfat al-Dîniyye, 2005.

Ibn Hazm, Abû Muhammed Ali bin Ahmad bin Saîd, Al-Fasl fi al-Milal wa'lahwâ wa al-Nihal. Beirut: Dar al-Jeel, 1996.

Ibn Majah, Abu Abdillah Muhammad b. Yazid al-Qazwini. Sunan. Riyadh: Dar al-Salam, n.d.

Ibn Manzur, Ebu al-Fazl Jamâluddîn Muhammed b. Mukarram b. Ali b. Ahmad al-Ansârî erRuwayfî, Lisān al-'Arab. Beirut: Dar al-Sadr, 1994. 
Ibn Sa'd, Abu Abdillah Muhammad b. Sa'd al-Zuhri, Al-Tabaqat al-Kubra. Beirut: Dar Sadir, n.d.

Ibn Taymiyyah, Abu Abbâs Takıyyuddîn Ahmad b. Abdulhalim, Kitâb al-Imân. Beirut: al-Maktaba al-Islâmiyye, 1996.

Kalyoncu, Mehmet, A Civilian Response to Ethno-Religious Conflict: The Gulen Movement in Southeast Turkey. New Jersey: The Light Inc., 2008.

Malik b. Anas Abu Abdillah, Muwatta. Cairo: Maktabah al-Taqwa, 2001.

Mercan, Faruk, Fethullah Gulen, Doğan Kitap. Istanbul, 2008.

Mercan, Faruk, M. Fethullah Gülen: Allah Yolunda Bir Ömür. Canada: Süreyya Publishing, 2019.

Michel Thomas, "Fethullah Gulen as Educator", Turkish Islam and the Secular State: The Gulen Movement, ed. M. H. Yavuz and J. L. Esposito, Syracuse, NY, Syracuse University Press, 2003

Muslim, Abu al-Husain Muslim b. Hajjaj b. Muslim al-Kushayri al-Nisaburi, Sahih, Dar al-Sha'b Publishing, Cairo, 1901.

Nasai, Abu Abd al-Rahman Ahmad b. Shua'ib b. Ali b. Sinan, Sunan, I-VIII, Matbaa Mustafa al-Babi al-Halabi wa Awladuhu Publishing, Cairo, 1964.

Nursi, Bediuzzaman Said, Hutbe-i Şamiye (Risale-i Nur Külliyatından). Mega Publishing, Istanbul, 2000.

İşaratü'l-İ'câz fî Mazanni'l-Îcâz. Istanbul; Şahdamar Publishing, 2014.

. Lemalar (Flashes). Istanbul; Şahdamar Publishing, 2014.

. Munazarat, Prep. Abdullah Aymaz. Istanbul; Şahdamar Publishing, 2006.

Tarihçe-i Hayat. Istanbul; Şahdamar Publishing, 2014.

---------. The Letters. Istanbul; Şahdamar Publishing, 2014.

Rumi, Mevlana Celaleddin. Mektuplar/Letters, Trans. Abdülbaki Gölpınarlı, Istanbul, 1953

Sarıçam, İbrahim, Hz. Muhammed ve Evrensel Mesajı. Ankara: Diyanet İşleri Başkanlığı, 2001.

Shahristânî, Abu al-Fath Muhammed b. Abdülkerim, El-Milel ve'n-nihal. Beyrut: Dâru'l-Marife, 1993.

Suyûtî, Jalalluddin, Al-Jâmi' al-Saghîr, trans. to Turkish, Group. Istanbul: Yeni Asya Publishing, 2002.

Tirmidhi, Abu Isa Muhammad b. Isa, Sunan, I-V. Cairo: Matbaa Mustafa al-Babi al-Halabi wa Awladuhu Publishing, 1938.

Ulu, Ömer, Gediğini Arayan Taşlar. Istanbul: Sistem Matbaacılık, 2001.

Vakkasoğlu, Vehbi, Başkasının Günahına Ağlayan Adam. Istanbul: Nesil Publishing, 2005.

http://www.herkul.org/kirik-testi/kirik-testi-kullukta-derinlesme/

https://hizmetten.com/helal-lokma-ve-iffetli-nesiller/

http://fgulen.com/en/press/news-en/today-s-zaman-hizmet-contribution-to-global-peacediscussed-in-addis-ababa

http://fgulen.com/en/press/news-en/todays-zaman-us-professor-carter-fethullah-gulenstruggles-for-peace-against-poverty-and-terrorism

http://fgulen.com/tr/eserleri/kalb-ibresi/dine-hizmet-mazhariyeti;

http://fgulen.com/tr/eserleri/prizma/mantik-ve-his-dengesi 
http://thecrcl.ca/misafir-yazar-bahattin-karatas-hizmet-hareketinin-dogu-ve-guneydoguyakazandirdiklari/

http://www.balkanalysis.com/blog/2006/03/09/conversations-with-the-assyrians-of-mardin/ http://www.balkanalysis.com/blog/2006/03/09/conversations-with-the-assyrians-of-mardin/ http://www.fgulen-com-kurt-meselesi-ve-cozum-recetesi http://www.herkul.org/bamteli/bamteli-sadakat-iksiri-ve-duraganlik-zehri/ http://www.herkul.org/bamteli/gaflet/ http://www.herkul.org/herkul-nagme/504-nagme-yangin-o-recete-ve-gaflet/ http://www.herkul.org/herkulden-bir-demet-hadis/haftanin-hadis-i-serifi/ http://www.herkul.org/kirik-testi/cocuk-terbiyesinde-denge/ http://www.herkul.org/kirik-testi/fedakarlik-olcusu-ve-infakta-denge/ http://www.herkul.org/kirik-testi/gelecegi-insa-edecek-fikir-mimarlari/ http://www.herkul.org/kirik-testi/kirik-testi-dusunce-ve-aksiyon-insani/ http://www.herkul.org/kirik-testi/kirik-testi-kullukta-derinlesme/ http://www.herkul.org/tag/fedakarlik/ http://www.herkul.org/tag/gaflet/ http://www.herkul.org/tag/gozyasi/ http://www.herkul.org/tag/gozyaslari/ http://www.herkul.org/tag/huzun-peygamberi/ http://www.herkul.org/tag/kurt-meselesi/ http://www.herkul.org/tag/sefkat/ http://www.herkul.org/tag/sevgi/ http://www.ozgurherkul.org/bamteli/helal-haram-hassasiyeti-ve-zehirli-lokmalar/. http://www.ozgurherkul.org/kirik-testi/fedakarlik-ve-adanmis-ruhlar/ https://en.wikipedia.org/wiki/Bank_Asya https://en.wikipedia.org/wiki/Turkish_Confederation_of_Businessmen_and_Industrialists https://fgulen.com/en/fethullah-gulens-life-en/the-art-of-coexistence-pioneering-role-offethullah-gulen-and-hizmet-movement/the-hizmet-movement-and-its-contribution-to-theglobal-peace-and-tolerance

https://fgulen.com/tr/basindan-tr/dizi-yazilar-dosyalar/ozel-dosyalar/fgulen-com-kurtmeselesi-ve-cozum-recetesi

https://fgulen.com/tr/basindan-tr/haberler/Zaman-Turk-Okullari-Dunya-Genelinde-BarisAdalari-Gibi

https://fgulen.com/tr/eserleri/kirik-testi/arsin-altinda-golgelenecek-yedi-zumre https://fgulen.com/tr/eserleri/namaz/islam-hakikati?start=6 https://tr.wikipedia.org/wiki/Zaman_(gazete) https://web.archive.org/web/20180920164410/http://hpaba.com/pages/en/ALEXIS\%20CAR REL\%20Man\%20the\%20Unknown\%201935.pdf 
Vol. 2 No. 1, 2020

https://www.fethullah-gulen.org/op-ed/three-greatest-enemies-ignorance-poverty-anddisunity.html

https://www.gulenmovement.com/gulen-movement/what-is-the-gulen-movement

https://www.tr724.com/omrumu-ulkem-bolunmesin-milletim-kamplasmasin-diye-vakfettim/ https://www.tr724.com/omrumu-ulkem-bolunmesin-milletim-kamplasmasin-diye-vakfettim/ https://www.turkishnews.com/tr/content/2011/11/15/gulenin-kurt-sorununa-cozumyaklasimi-pkkyi-panikletti/

https://www.youtube.com/watch?v=dCg5AHvTgos

https://www.youtube.com/watch?v=IrFdZvo98tQ

https://www.youtube.com/watch?v=NgSGQ-DtSY8

https://www.youtube.com/watch?v=y5_fziE0Rps 